\title{
The complete chloroplast genome of Dendrobium nobile, an endangered medicinal orchid from northeast India and its comparison with related Dendrobium species
}

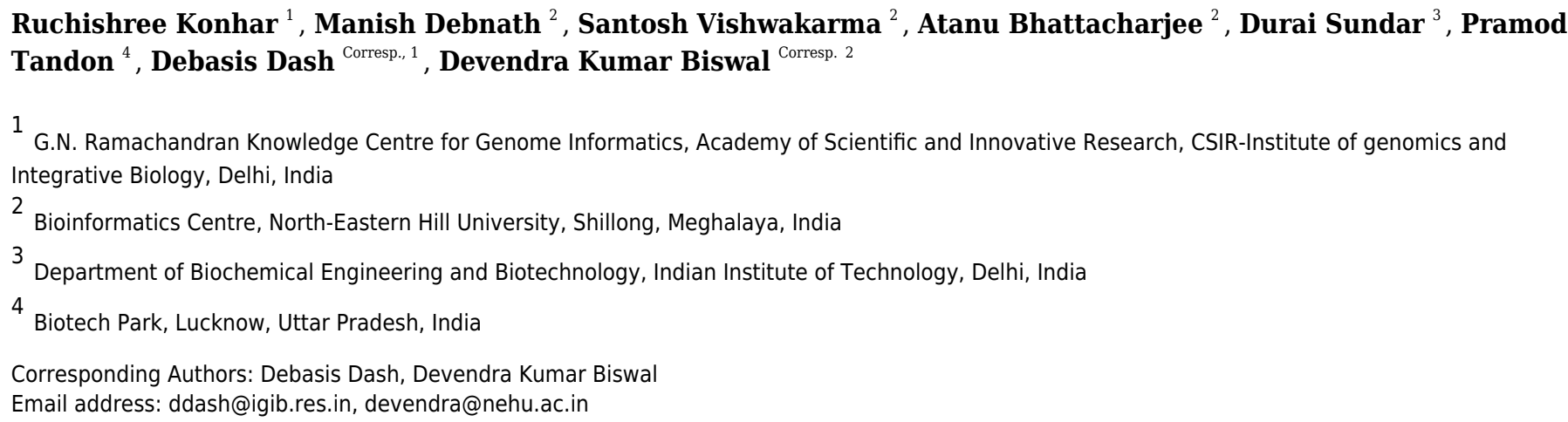

The medicinal orchid genus Dendrobium belonging to the Orchidaceae family is a huge genus comprising about 800-1500 species. To better illustrate the species status in the genus Dendrobium, a comparative analysis of 33 available chloroplast genomes retrieved from NCBI Refseq database was compared with that of the first complete chloroplast genome of $D$. nobile from north-east India based on next-generation sequencing methods (Illumina HiSeq 2500-PE150). Our results provide comparative chloroplast genomic information for taxonomical identification, alignment-free phylogenomic inference and other statistical features of Dendrobium plastomes, which can also provide valuable information on their mutational events and sequence divergence. 


\section{The Complete chloroplast genome of Dendrobium nobile, an endangered}

2 medicinal orchid from northeast India and its comparison with related

3 Dendrobium species.

4 Ruchishree Konhar ${ }^{1,2 \#}$, Manish Debnath ${ }^{1}$, Santosh Vishwakarma ${ }^{1}$, Atanu Bhattacharjee ${ }^{1}$, Durai

5 Sundar $^{3}$, Pramod Tandon ${ }^{4}$, Debasis Dash ${ }^{2^{*}}$, Devendra Kumar Biswal ${ }^{{ }^{*}}$

$6 \quad{ }^{1}$ Bioinformatics centre, North-Eastern Hill University, Shillong, Meghalaya, India

$7 \quad{ }^{2}$ G.N. Ramachandran Knowledge Centre for Genome Informatics, Academy of Scientific and

8 Innovative Research, CSIR-Institute of genomics and Integrative Biology, Delhi, India

9 32Department of Biochemical Engineering and Biotechnology, Indian Institute of Technology,

10 Delhi, India

$11{ }^{4}$ Biotech Park, Lucknow, Uttar Pradesh, India

$12{ }^{\#}$ Current affiliation

$13{ }^{*}$ Corresponding author (s)

15 CORRESPONDING AUTHORS

16 Debasis Dash ${ }^{2}$

17 Email: ddash@igib.res.in

18 Devendra Kumar Biswal ${ }^{1}$ *

19 Email: devbioinfo@gmail.com

\section{Abstract}

21 The medicinal orchid genus Dendrobium belonging to the Orchidaceae family is a huge genus 22 comprising about 800-1500 species. To better illustrate the species status in the genus 23 Dendrobium, a comparative analysis of 33 available chloroplast genomes retrieved from NCBI 24 Refseq database was compared with that of the first complete chloroplast genome of D. nobile 25 from north-east India based on next-generation sequencing methods (Illumina HiSeq 250026 PE150). Our results provide comparative chloroplast genomic information for taxonomical 27 identification, alignment-free phylogenomic inference and other statistical features of 
Dendrobium plastomes, which can also provide valuable information on their mutational events and sequence divergence.

\section{Introduction}

Dendrobium is a huge genus of the tribe Dendrobieae (Orchidaceae: Epidendroideae) that was established by Olof Swartz in 1799. It includes approximately 800-1500 species and occurs in diverse habitats throughout much of Southeast Asia, including China, Japan, India, and the Philippines, Indonesia, New Guinea, Vietnam, Australia and many of the islands in the Pacific. [1].

Many species and cultivars of this genus are well-known floral motifs and have featured in artwork. Dendrobium orchids are popular not only for their visual appeal in cut flower market, but also for their herbal medicinal history of about 2000 years in east and south Asian countries [2]. Many species in this genus have been extensively used as herbal medicines for several hundreds of years in treating diseases like kidney and lung ailments, gastrointestinal problems, lumbago and arthralgia. The plant extracts are also used as tonic for strengthening body's immunity and improving sexual potency. However, many Dendrobium species in the wild face an extreme threat of extinction due to their low germination and slow growth rate, habitat decline and over exploitation arising out of anthropogenic activities [3].

Dendrobium orchids have overwhelmed researchers because of their high economic importance in global horticultural trade and in Asian traditional medicine leading to extensive plant systemic studies particularly in species identification, novel marker development, breeding and conservation. In the past two decades, promising advances have been made in areas of molecular taxonomy, plant systematics and selective breeding of Dendrobium species by intensive use of molecular markers. Recently, a variety of molecular markers like microsatellite (SSR), Random Amplified Polymorphic DNA (RAPD) and Amplified Fragment Length Polymorphism (AFLP) markers including several other DNA barcode markers from different loci of nuclear and chloroplast (cp) regions have been developed to study Dendrobium diversity. However, these species are notoriously difficult to identify [4].

The complete chloroplast (cp) genome usually contains a uniparentally inherited DNA, a feature which makes it an obvious choice for plant taxonomical analyses, phylogenomics and phylogeographic inferences at different taxonomic levels. One such classic example is the study 
59 of phylogenetic relationships among all families in the Order Liliales, based on 75 plastid genes

60 from 35 species in 29 genera and 100 species spanning all monocot and major eudicot lineages,

61 where underlying results were calibrated against 17 fossil dates to redefine the monocot

62 evolutionary timelines [5]. The significance of plastome-scale data was very well demonstrated

63 in another study that highlighted a new functional model for understanding monocot evolution

64 and some of their derived morphological features by way of convergent evolution from

65 submersed aquatic ancestors (aquatic Hydatellaceae) [6]. The evolution of orchids, the largest

66 and most diverse family of flowering plants second only to Asteraceae on Earth has long puzzled

67 Charles Darwin and many other scientists. Recent advances in chloroplast genomics are giving

68 researchers insights into the evolutionary history of these plants. One such study hypothesizes

69 orchids to have arisen in Australia $112 \mathrm{Ma}$ followed by migration to the Neotropics via 70 Antarctica by $90 \mathrm{Ma}$. With the use of a combination of plastid genes, it was established that orchids and epidendroids exhibited maximally accelerated net diversification in Southeast Asia 72 and the Neotropics respectively [7].

73 Studies pertaining to plastome genome sequences are useful in investigating the maternal 74 inheritance in plants, especially those with polyploid species, owing to their high gene content and conserved genome structure [8,9 \& 10]. Many species of orchids and other flowering plants exhibit rapid evolution and diversity. One of the main reasons for such diversity can be attributed to allopolyploidy or genetic redundancy, in which there are more than one gene involved in performing a particular task. In cases of useful mutation, plants evolve into new species. Hybridization and polyploidy are the decisive forces behind evolution and speciation. In the past there have been studies where a combination of AFLPs, cpDNA markers and flow cytometry was harnessed to investigate the evolutionary outcomes of hybridization between two endemic Ecuadorian species of Epidendrum (Orchidaceae) in three hybrid zones. The outcome of this study highlights the importance of hidden hybrid genotypes and their frequency which could help unravel the mysteries behind orchid evolution [11]. The advent of high-throughput sequencing technologies has enabled a rapid increase in the rate of completion of $\mathrm{cp}$ genomes with faster and cheaper methods to sequence organellar genomes [12, 13]. At the time of writing this manuscript, cp genomes from 33 Dendrobium species have been reported as per NCBI 
D. nobile Lindl. is one of the many highly prized medicinal plants in the genus

91 Dendrobium. It is an endangered medicinal orchid listed in the Convention on International

92 Trade in Endangered Species of Wild Fauna and Flora (CITES) Appendix II that demands

93 immediate attention for its protection and propagation. Here, we report the first complete $\mathrm{cp}$

94 genome of $D$. nobile from north-east India based on next-generation sequencing methods

95 (Illumina HiSeq 2500-PE150) and further compare its structure, gene arrangement and

96 microsatellite repeats with 33 existing cp genomes of Dendrobium species. Our results provide

97 comparative chloroplast genomic information for taxonomical identification, phylogenomic

98 inference and other statistical features of Dendrobium plastomes. These can give further insights

99 into their mutational events and sequence divergence. The availability of complete cp genome

100 sequences of these species in the genus Dendrobium will benefit future phylogenetic analyses

101 and aid in germplasm utilization of these plants.

102

103 Materials and Methods

\section{Sample collection, DNA extraction and sequencing}

105 Fresh leaves of $D$. nobile were collected from plants growing in greenhouses of National

106 Research Centre for Orchids, Sikkim, India and voucher specimen was deposited in Botanical

107 Survey of India as well as in the Department of Botany, North Eastern Hill University, Shillong.

108 The high molecular weight cp DNA was extracted using a modified CTAB buffer, and treated

109 according to a standard procedure for next generation sequencing on Illumina HiSeq 2500-

110 PE150. The quality and quantity of the genomic DNA was assessed through agarose gel

111 electrophoresis, Nanodrop and Qubit detection method. The experiments included both paired-

112 end and mate-pair libraries. Tagmentation was carried out with $\sim 4 \mu \mathrm{g}$ of Qubit quantified DNA

113 and the tagmented sample was washed using AMPURE XP beads (Beckman Coulter \#A63881)

114 and further exposed to strand displacement. The strand-displaced sample of $2-5 \mathrm{~kb}$ and $8-13 \mathrm{~kb}$

115 gel was size selected and taken for overnight circularization. The linear DNA was digested using

116 DNA Exonuclease. Further the circularized DNA molecules were sheared using Covaris

117 microTUBE, S220 system (Covaris, Inc., Woburn, MA, USA) for obtaining fragments in the

118 range 300 to $1000 \mathrm{bp}$. M280 Streptavidin beads (ThermoFisher Scientific, Waltham, MA) was

119 used to cleanse the sheared DNA fragments with biotinylated junction adapters. The bead-DNA

120 complex was subjected to End repair, A-Tailing and Adapter ligations. 


\section{Data processing}

123 The data quality assessment for Illumina WGS raw reads was carried out using FastQC tool. Perl

124 scripts were written for adapter clipping and low quality filtering. Cp genomes of D. officinale, 125 D. huoshanense and D. strongylanthum retrieved from NCBI-Refseq database was used as 126 reference for the assembly. BWA-MEM algorithm with default parameter settings was used for

127 aligning the adapter clipped and low quality trimmed processed reads with the Dendrobium $\mathrm{cp}$ 128 genomes [14]. SPAdes-3.6.0 program was used for k-mer based (k-mer used 21, 33, 55 and 77) 129 de-novo assembly with the aligned reads and the quality of the assembled genome was gauged 130 using Samtools and Bcftools (read alignment and genome coverage calculation) [15] 131 (https://samtools.github.io/bcftools/bcftools.html). The cp genome of $D$. nobile was also 132 generated through reference-assisted assembly using the high quality paired-end libraries by 133 NOVOPlasty [16] for further validation. It is specifically designed for de novo assembly of 134 mitochondrial and $\mathrm{cp}$ genomes from WGS data with the aid of a reference or seed sequence. The 135 seed sequence can correspond to partial or complete sequence of chloroplasts of closely to 136 distantly related species. The cpDNA refseq sequence of $D$. officinale was used as a seed 137 sequence to perform reference-assisted assembly.

\section{Genome annotation and codon usage}

140 Basic Local Alignment Search Tool (BLAST; BLASTN, PHI-BLAST and BLASTX) [17], 141 chloroplast genome analysis platform (CGAP) [18] and Dual Organellar GenoMe Annotator 142 (DOGMA) [19] was used to annotate protein-coding and ribosomal RNA genes. The boundaries 143 of each annotated gene with putative start, stop, and intron positions were manually determined 144 by comparison with homologous genes from other orchid cp genomes. Further tRNA genes were 145 predicted using tRNAscan-SE [20] and ARAGORN [21]. RNA editing sites in the protein146 coding genes (PCG) of D. nobile were predicted using Plant RNA Editing Prediction \& Analysis 147 Computer Tool (PREPACT) (http://www.prepact.de). For this analysis, D. nobile cp genome was 148 BLAST aligned against Nicotiana tabacum, Oryza sativa Japonica Group, Phalaenopsis 149 aphrodite subsp. Formosana, Physcomitrella patens subsp. patens and Zea mays with a cutoff 150 E-value set to 0.08. The circular genome map was drawn in OrganellarGenomeDRAW [22] 151 followed by manual modification. The sequencing data and gene annotation were submitted to 
152 GenBank with accession number KX377961. MEGA 7 was used to analyze and calculate GC

153 content, codon usage, nucleotide sequence statistics and relative synonymous codon usage

154 (RSCU) [23].

155

156 Gene Ontology annotation and assignment of GO IDs

157 Gene Ontology (GO) annotation of D. nobile chloroplast genes was carried out in Blast2go [24]

158 by blast aligning the gene sequences from the GenBank annotation files to Orchidaceae 159 sequences in non-redundant (nr) database with an e-value cutoff of $1 \mathrm{e}^{-5}$ and queried in 160 InterProScan [25]. GO mapping and annotation of genes followed this from blast results and 161 were subsequently merged with GO IDs from InterProScan. The merged GO annotations were 162 validated based on True-Path-Rule by removing redundant child terms for each gene sequence. 163 The GO annotations were slimmed down using plant-slim option.

164

\section{Simple sequence repeats analysis}

166 MISA (http://pgrc.ipk-gatersleben.de/misa/misa.html), a tool for identification and location of 167 perfect microsatellites and compound microsatellites was used to search for potential simple 168 sequence repeats (SSRs) loci in the cp genomes of different Dendrobium species. The threshold 169 point for SSRs identification was set to 10, 5, 4, 3, and 3 for mono-, di-, tri-, tetra-, and penta170 nucleotides SSRs, respectively. All the repeats found were manually curated and the redundant 171 ones were removed.

172

173 Phylogenetic reconstruction with whole genome alignment and rearrangement analysis

174 For phylogenetic reconstruction, we included D. nobile cp genomes from India and China along 175 with 32 other Dendrobium cp genomes retrieved from GenBank. Four Goodyera species were 176 taken as outgroup. The cp genome sequences were aligned with MAFFT v7.0.0 [26] and 177 manually curated by visual inspection. PCGs as well as whole cp genomes were used for 178 bayesian phylogenetic reconstruction using MRBAYES 3.2.6 [27]. To further validate our results 179 we employed "K-mer Based Tree Construction" in CLC Genomics Workbench that uses single 180 sequences or sequence lists as input and creates a distance-based phylogenetic tree. For 181 visualization and testing the presence of genome rearrangement and inversions, gene synteny 182 was performed using MAUVE as implemented in DNASTAR 12.3 with default settings. 
183 Comparative analysis of intra nucleotide diversity $(P i)$ within the Dendrobium cp genomes was 184 performed using MEGA 7.

185

186 Single Nucleotide Polymorphism identification and phylogenetic analysis without genome 187 alignment

188 Phylogenetic tree was constructed based on the Single Nucleotide Polymorphisms (SNPs) 189 identified in the whole cp genomes using kSNP3.0 with default settings except for k-mer size 190 [28]. SNPs were identified with k-mer size set to 23, based on which, approximately $79 \%$ of the 191 k-mers generated from median-length genome were unique.

192

\section{Results}

\section{Genome organization and features}

195 The complete cp genome of $D$. nobile was determined from the data generated out of a whole genome project initiative of the same species by Paired-end and Mate pair data from Illumina

197 HighSeq with $150 * 2$ and Illumina NextSeq500 with $75 * 2$ respectively. Further the aligned Illumina reads were separated and assembled using CLC Main Workbench Version 7.7.1 into the single longest scaffold. The $D$. nobile cp genome is a typical circular double-stranded DNA with a quadripartite structure; it is 152,018 bp in size and consists of Large Single Copy (LSC) (1..84,944; 84,944 bp), Small Single Copy (SSC) $(111,230 . .125,733 ; 14504$ bp), and two Inverted Repeat (IR) regions of 26,285 bp: IRA $(84,945 . .111,229)$ and IRB $(125,734 . .152018)$. In total 134 unique genes (79 PCGs, 8 rRNA genes, 7 pseudogenes and 38 tRNA genes) were successfully annotated, of which 12 genes rps16, atpF, rpoC1, ycf3, rps12 (2), clpP, petB, rpl2 (2), ndhB (2)\} are reported with introns (Fig. 1). We could identify a total of 20,81 and 11 genes duplicated in the IR, LSC and SSC regions respectively in the D. nobile cp genome. There were a total of 49 RNA editing sites predicted in 23 genes of $D$. nobile cp genome. The whole chloroplast genome alignment included 34 Dendrobium species and 4 species from the genus Goodyera as outgroup. Each genome's panel contained its name, sequence coordinates and a 210 black coloured horizontal centre line with coloured block outlines appearing above and below it. 211 Homology between the cp genomes is represented by each block with the genes, internally free

212 from genomic rearrangement, connected by thin lines to similarly coloured blocks depicting 213 comparative homology between the genomes (Fig. 2). The positions of LSC/IRA/SSC/IRB 
214 borders revealed similar structures at the IR/LSC junction in the overall alignment of

215 Dendrobium whole cp genomes (Fig. 3).

216

217 Gene Ontology mapping and annotation

218 We further analyzed the D. nobile coding cp genome sequences using the Blast2GO suite and 219 annotated the sequences for three GO terms (biological process, molecular function, and cellular 220 component). In case of GO term there were a total of 231 annotations in biological process (P) 221 molecular Function and cellular compartment (C) level. In the category of biological processes a 222 large number of these sequences are annotated for translation, photosynthesis, metabolic 223 processes, and ribosome biogenesis. Similarly, for the GO term molecular function, the top GO 224 categories include functions related to structural molecule activity, catalytic activity, ion and 225 rRNA binding, transporter and transferase activity. Finally, terms including membrane, ribosome 226 and thylakoid were annotated GO categories for cellular compartment with most of the 227 sequences. These results are summarized along with the information on RNA editing sites in 228 Table 1.

229

\section{Simple sequence repeat identification}

231 SSRs were identified in MISA perl scripts with a minimum of $10 \mathrm{bp}$ repeats among all the 232 Dendrobium species. Of all the SSRs, the mononucleotide A/T repeat units occupied the highest 233 proportion. A higher proportion of di-, tri- repeats are reported rather than tetra- and penta234 nucleotide repeats across Dendrobium cp genomes (Fig. 4).

\section{Phylogenetic analysis}

Phylogenetic analyses of chloroplast PCGs from Dendrobium species were performed with or without partitions of sequences. Both bayesian and K-mer based trees (Figs. 5 and 6) recovered a monophyly of the Dendrobium species, irrespective of whether or not the partitions of sequences were incorporated in the analysis supported by strong bootstrap values. The phylogenetic analyses based on complete cp genomes, suggested that five major subgroups within the genus

242 Dendrobium evolved in a nested evolutionary relationship. D. aphyllum, D. parishii, D.

243 loddigesii and $D$. primulinum are the most recently evolved species that nested into a single 244 monophyletic sub group within the Dendrobium clade. D. chrysotoxum and D. salaccense were a 
245 bit primitive on the evolutionary ladder in the phylogenetic tree. Goodyera species emerged as 246 the outgroup that claded separately in the over all tree topology. Similar results were also 247 obtained in the alignment free phylogenetic tree with SNPs (Fig. 6).

248

249 Discussion

250 Potential RNA editing sites

251 RNA editing is involved in plastid posttranscriptional regulation and thus provides an effective 252 way to create transcript and protein diversity [29, 30]. In Orchidaceae, RNA editing sites were 253 identified in 24 protein-coding transcripts in $P$. aphrodite [31]. Earlier studies indicate RNA 254 editing sites from the same subfamily to be more conserved than those from different subfamily

255 [32]. However, orchids and other angiosperms have relatively less common editing sites. For 256 example, orchids and Cocos nucifera share 10 potential RNA editing sites; comparisons among Nicotiana tabacum, Arabidopsis thaliana and orchid RNA editing sites have shown low conservation of editing sites (one common editing site in rpoB) [32]. Our studies congruently predicted all 49 RNA editing sites (Table 1) in 23 genes of D. nobile from at least $75 \%$ of the reference organisms (Nicotiana tabacum, Oryza sativa Japonica Group, Phalaenopsis aphrodite subsp. Formosana, Physcomitrella patens subsp. Patens and Zea mays) and resulted in amino acid substitutions. All the RNA-editing sites were non-silent and edited C to U. Of the 49 RNA editing sites $89.8 \%$ (44) editing sites appeared in the second position of triplet codon, $10.2 \%$ (5) editing sites appeared in the first position of triplet codon whereas no editing sites appeared in the third base of triplet codon. The genes ndhD, rpoB, rpoC1 had 8, 6 and 4 RNA editing sites respectively. All the 49 RNA editing sites led to changes in the amino acid. The most frequent amino acid conversion was hydrophilic to hydrophobic ( $\mathrm{S}$ to $\mathrm{L}, 22$ occurrences and $\mathrm{S}$ to $\mathrm{F}, 8$ occurrences), followed by hydrophobic to hydrophobic conversions (P to L, 12 occurrences). Seven conversions were found to be hydrophilic to hydrophilic ( $\mathrm{H}$ to $\mathrm{Y}, 5$ occurrences and $\mathrm{T}$ to M, 2 occurrences).

271

\section{Comparison with other chloroplast genomes within the genus Dendrobium}

273 We compared thirty-four chloroplast genomes representing different species within the genus 274 Dendrobium (Table 2). The length of the Dendrobium species cp genomes ranged from 148,778 275 to $153,953 \mathrm{bp}$, with $D$. chrysotoxum being the largest cp genome and $D$. moniliforme the 
276 smallest. The $\mathrm{cp}$ genomes have acquired the familial angiosperm plastome organization 277 comprising of a LSC, an SSC and a pair of IR regions each. Dendrobium cp genomes are also 278 AT-rich (62.26-62.39\%) quite similar to other orchid cp genomes [33]. Differences in the cp 279 genome size of these species are primarily due to the variations in the length of LSC, SSC and IR 280 regions. Synteny comparison revealed a lack of genome rearrangement and inversions, thereby, 281 substantiating for the highly conserved nature in the genomic structure, including gene number 282 and gene order in these cp genomes. However, structural variation was predominant in the 283 LSC/IR/SSC boundaries (Fig. 2), which could be harnessed for predicting potential biomarkers 284 for species identification.

285 IR regions are generally considered to be highly conserved regions in the chloroplast 286 genome. IR expansion or contraction is determined by the variability of genes flanking IR/SC 287 junctions [27]. In the evolutionary ladder, SSC and IR border regions experience expansion and 288 contraction that overall contribute to the variation in chloroplast genome length [34, 35]. At the 289 IR/LSC boundaries, most IRs of non-orchid monocots exhibit trnH-rps19 gene clusters, 290 excluding Irpl22 genes, leading to more-progressive expansion of IRs compared to non291 monocot angiosperms [36, 37]. Contrarily, the orchid chloroplast genomes have distinct 292 characteristics at the IR/SSC junction and are classified into four types based on the organization 293 of genes flanking the $\mathrm{IR}_{\mathrm{B}} / \mathrm{SSC}$ junction $\left(\mathrm{J}_{\mathrm{SB}}\right)$. In type $\mathrm{I}$ structure, $\mathrm{J}_{\mathrm{SB}}$ is located upstream of 294 the $n d h \mathrm{~F}-r p l 32$ cluster and is primarily seen in Cypripedium and Dendrobium species. Type II 295 junction is found in Cymbidium species in which $\mathrm{J}_{\mathrm{SB}}$ is located within $\Psi y c f 1$ and $n d h \mathrm{~F}$ genes. 296 Type III is reported in Oncidium, Erycina, and Phalaenopsis equestris, in which $\mathrm{J}_{\mathrm{SB}}$ is located 297 inside the $\Psi y c f 1$-rpl32 cluster, with the loss of $n d h \mathrm{~F}$ gene. The type IV structure is characterized 298 by the incorporation of the entire $y c f 1$ into the $\mathrm{SSC}$, with $\mathrm{J}_{\mathrm{SB}}$ inside trnN-rpl32 [28]. In the 299 present study, the positions of LSC/IRA/SSC/IRB borders were examined in the overall 300 alignment of Dendrobium whole cp genomes and all of them were found to have similar 301 structures at the IR/LSC junction akin to type I structure (Fig. 3). Previous studies emphasize 302 that IR expansion or contraction may not correlate with the taxonomic relationships [29]. More 303 molecular data is required for enhancing our present understanding of the genes flanking IR/SSC 304 junctions and their underlying variations. 
A comparative nucleotide sequence statistics (counts of annotations, AT/GC counts,

307

308

309

310

311

312

313

314

315

316

317

318

319

320

321

322

323

324

325

326

327

328

\section{Gene ontology analysis}

330 The GO annotation revealed majority of the chloroplast genes are involved in the process of 331

332

333

334

335 nucleotide frequency in codon positions etc.) for all the Dendrobium species including representatives from outgroup are outlined in Tables 3, 4 and 5. The relative synonymous codon usage is given in parentheses following the codon frequency (averages over all taxa) involved (Table 6). Maximum Likelihood analysis of natural selection codon-by-codon was carried out. For each codon, estimates of the numbers of inferred synonymous (s) and nonsynonymous (n) substitutions are presented along with the number of sites that are estimated to be synonymous (S) and nonsynonymous (N) (Table S1). These estimates were calculated using the joint Maximum Likelihood reconstructions of ancestral states under a Muse-Gaut model [38] of codon substitution and Felsenstein 1981 model [39] of nucleotide substitution. For estimating ML values, a tree topology was automatically computed. The test statistic dN - dS was used for detecting codons that have undergone positive selection, where dS is the number of synonymous substitutions per site $(\mathrm{s} / \mathrm{S})$ and $\mathrm{dN}$ is the number of nonsynonymous substitutions per site $(\mathrm{n} / \mathrm{N})$. A positive value for the test statistic indicates an overabundance of nonsynonymous substitutions. In this case, the probability of rejecting the null hypothesis of neutral evolution (Pvalue) was calculated $[40,41]$. Values of $\mathrm{P}$ less than 0.05 are considered significant at a $5 \%$ level and are highlighted [Table S2]. Normalized dN - dS for the test statistic is obtained using the total number of substitutions in the tree (measured in expected substitutions per site). The analysis involved 38 nucleotide sequences. Codon positions included were $1 \mathrm{st}+2 \mathrm{nd}+3 \mathrm{rd}+$ Noncoding and all positions containing gaps and missing data were eliminated. There were a total of 108,594 positions in the final dataset.

translation, photosynthesis, ion transport and transcription (Table 1). The molecular functions of the genes are majorly binding - RNA, metal ion, DNA, ion and electron transport, RNA polymerase activity and various other enzymatic activities. Enzyme classification showed seven genes to be translocases, four as transferases, two as oxidoreductases, and one each as hydrolase, lyase and ligase. A majority of the genes encode proteins localizing in chloroplast thylakoid 
336 membrane, ribosome and few are transported to the mitochondria. The ndhB gene is involved in

337 photosynthesis, while rpoB and rpoC1 are involved in biosynthetic process.

338

339 Characterization of simple sequence repeats

340 Previous studies have documented prevalence of mononucleotide and dinucleotide SSRs in 341 atleast 15 Dendrobium species from 92 syntenic intergenic and intronic loci. Of all these loci, $34210\{$ (mutational hotspots: psbB-psbT, rpll6-rps3, trnR-atpA, and trnL intron); (ndhF-rpl32, 343 rpl32-trnL, rps 16-trnQ, and $\operatorname{trnE-trnT)\} }$ are reported to be the fastest evolving and are termed as 344 top ten hotspots [29]. The SSRs lying in these regions could be further investigated for 345 identifying potential markers that can aid in barcoding analysis.

347 Phylogenetic analyses

348 In the present study, we employed two different approaches for phylogeny reconstruction. First 349 we aligned the whole cp genomes and exported the alignment matrices for creating a Bayesian 350 tree (Fig. 5). Two independent MCMC chains were run with first $25 \%$ of the cycles removed as 351 burn-in, coalescence of substitution rate and rate model parameters were also examined and 352 average standard deviation of split frequencies was carried out and generations added until the 353 standard deviation value was lowered to 0.01 . Secondly we performed a phylogenetic tree 354 construction using an alignment free approach. In this case we identified the SNPs from the cp 355 genomes and utilised them in constructing the phylogenetic tree (Fig. 6). A total of 13,839 SNPs were identified in the 38 genomes analyzed, of which 2,203 were homoplastic SNPs i.e. SNPs that do not correspond to any node in the parsimony tree. The fraction of k-mers present in all genomes is 0.482 . The numbers at the nodes in the phylogenetic tree indicate the number of SNPs that are present in all of the descendants of that node and absent in others (Fig. 6). The numbers at the tips indicate the number of SNPs unique to each particular species.

361 The two different methods that employed both alignment and alignment-free approach resulted

362 in highly reliable identical phylogenetic trees within each data set. Different analyses based on 363 the two datasets generated largely congruent topologies (Figs. 5 and 6) with Dendrobium species 364 forming one clade and Goodyera species forming another clade as an outgroup.

\section{Conclusions}


367 This study provides the first comparative account on the complete chloroplast genome of $D$.

368 nobile from north-east India with 33 other species from the genus Dendrobium that revealed

369 higher sequence variation in SSC and LSC regions compared with IR regions in both coding and

370 non-coding regions. The gene order, gene content and genomic structure were highly conserved

371 with those of other sequenced Dendrobium species. However, IR contraction is observed within

372 the genus and several SNPs identified from these cp genomes were quite instrumental in

373 generating alignment-free robust phylogenetic trees that congrued with trees generated from

374 aligned matrices of whole $\mathrm{cp}$ genomes. This gives an indication that the SNPs, insertions and

375 deletions, LSC and SSC regions in the cp genomes of this medicinal orchid genus can be utilized

376 for barcoding and biodiversity studies. Further this would augment more and more plastome

377 sequencing of Dendrobium species that are not reported in this study.

378

379

\section{References}

380

1. Wood, H. P. 2006. The Dendrobiums. Timber Press

381

2. Bulpitt CJ, Li Y, Bulpitt PF, Wang J. 2007..The use of orchids in Chinese medicine.

382

383 Journal of the Royal Society of Medicine 100(12):558-63

3. Kong JM, Goh NK, Chia LS, Chia TF. 2003. Recent advances in traditional plant drugs and orchids. Acta Pharmacologica Sinica 24(1):7-21

386

387

4. Teixeira da Silva JA, Jin X, Dobránszki J, Lu J, Wang H, Zotz G, Cardoso JC, Zeng S. 2016. Advances in Dendrobium molecular research: Applications in genetic variation, identification and breeding. Molecular Phylogenetics and Evolution 95:196-216

5. Givnish TJ, Zuluaga A, Marques I, Lam VKY, Gomez MS, Iles WJD, Ames M, Spalink D, Modeller JR, Jackson R, Briggs BG, Lyon SP, Stevenson DW, Zomlefer W, Graham SW. 2016. Phylogenomics and historical biogeography of the monocot order Liliales: Out of Australia and through Antarctica. Cladistics 32: 581- 605

6. Givnish TJ, Zuluaga A, Spalink D, Soto Gomez M, Lam VKY, Saarela JM, Sass C, Iles WJD, de Sousa DJL, Leebens-Mack J, Chris Pires J, Zomlefer WB, Gandolfo MA, Davis JI, Stevenson DW, dePamphilis C, Specht CD, Graham SW, Barrett CF, Ané C. 2018. Monocot plastid phylogenomics, timeline, net rates of species diversification, the power of multi-gene analyses, and a functional model for the origin of monocots. Am J Bot. 105(11):1888-1910 
398

399

400

401

402

403

404

405

406

407

408

409

410

411

412

413

414

415

416

417

418

419

420

421

422

423

424

425

426

7. Givnish TJ, Spalink D, Ames M, Lyon SP, Hunter SJ, Zuluaga A. 2016. Orchid historical biogeography, diversification, Antarctica and the paradox of orchid dispersal. J Biogeogr. 43:1905-16

8. Birky CW. 1995. Uniparental inheritance of mitochondrial and chloroplast genes: mechanisms and evolution. Proceedings of the National Academy of Sciences of the United States of America 92(25):11331-11338

9. Soltis PS, Soltis DE. 2000. The role of genetic and genomic attributes in the success of polyploids. Proceedings of the National Academy of Sciences of the United States of America 97(13):7051-7057

10. Song BH, Wang XQ, Wang XR, Sun LJ, Hong DY, Peng PH. 2002. Maternal lineages of Pinus densata, a diploid hybrid. Molecular Ecology 11:1057-1063

11. Marques I, Draper D, Riofrío L, Naranjo C. 2014. Multiple hybridization events, polyploidy and low postmating isolation entangle the evolution of neotropical species of Epidendrum (Orchidaceae). BMC Evol Biol. 14:20

12. Saski C, Lee SB, Fjellheim S, Guda C, Jansen RK, Luo H, Tomkins J, Rognli OA, Daniell H, Clarke JL. 2007. Complete chloroplast genome sequences of Hordeum vulgare, Sorghum bicolor and Agrostis stolonifera, and comparative analyses with other grass genomes. Theoretical and Applied Genetics 115(4):571-90.

13. Cronn R, Liston A, Parks M, Gernandt DS, Shen R, Mockler T. 2008. Multiplex sequencing of plant chloroplast genomes using Solexa sequencing-by-synthesis technology. Nucleic Acids Research 36(19):e122.

14. Li H, Durbin R. Fast and accurate short read alignment with Burrows-Wheeler transform. Bioinformatics. 2009 Jul 15;25(14):1754-60.

15. Bankevich A, Nurk S, Antipov D, Gurevich AA, Dvorkin M, Kulikov AS, Lesin VM, Nikolenko SI, Pham S, Prjibelski AD, Pyshkin AV, Sirotkin AV, Vyahhi N, Tesler G, Alekseyev MA, Pevzner PA. 2012. SPAdes: a new genome assembly algorithm and its applications to single-cell sequencing. Journal of Computational Biology 19(5):455-77.

16. Dierckxsens N, Mardulyn P, Smits G. 2017. NOVOPlasty: de novo assembly of organelle genomes from whole genome data. Nucleic Acids Res. 45(4): e18.

Peer) reviewing PDF | (2018:12:33661:2:0:NEW 7 Aug 2019) 
427

428

429

430

431

432

433

434

435

436

437

438

439

440

441

442

443

444

445

446

447

448

449

450

451

452

453

454

455

456

457

17. Altschul SF, Madden TL, Schäffer AA, Zhang J, Zhang Z, Miller W, Lipman DJ. 1997. Gapped BLAST and PSI-BLAST: a new generation of protein database search programs. Nucleic Acids Research 25(17):3389-402.

18. Cheng J, Zeng X, Ren G, Liu Z. 2013. CGAP: a new comprehensive platform for the comparative analysis of chloroplast genomes. BMC Bioinformatics 14:95.

19. Wyman SK, Jansen RK, Boore JL. 2004. Automatic annotation of organellar genomes with DOGMA. Bioinformatics 20(17):3252-5.

20. Lowe TM, Eddy SR. 1997. tRNAscan-SE: a program for improved detection of transfer RNA genes in genomic sequence. Nucleic Acids Research 25(5):955-64.

21. Laslett D, Canback B. 2004. ARAGORN, a program to detect tRNA genes and tmRNA genes in nucleotide sequences. Nucleic Acids Research 32(1):11-6.

22. Lohse M, Drechsel O, Kahlau S, Bock R. 2013. OrganellarGenomeDRAW--a suite of tools for generating physical maps of plastid and mitochondrial genomes and visualizing expression data sets. Nucleic Acids Res. 41(Web Server issue): W575-81.

23. Kumar S, Stecher G, Tamura K. 2016. MEGA7: Molecular Evolutionary Genetics Analysis Version 7.0 for Bigger Datasets. Molecular Biology and Evolution 33(7):1870-4

24. Conesa A, Götz S, García-Gómez JM, Terol J, Talón M, Robles M. 2005. Blast2GO: a universal tool for annotation, visualization and analysis in functional genomics research. Bioinformatics. 21(18): 3674-6

25. Jones P, Binns D, Chang HY, Fraser M, Li W, McAnulla C, McWilliam H, Maslen J, Mitchell A, Nuka G, Pesseat S, Quinn AF, Sangrador-Vegas A, Scheremetjew M, Yong SY, Lopez R, Hunter S. 2014. InterProScan 5: genome-scale protein function classification. Bioinformatics. 30 (9):1236-40.

26. Katoh K, Standley DM. 2013. MAFFT multiple sequence alignment software version 7: improvements in performance and usability. Molecular Biology and Evolution 30(4):77280

27. Huelsenbeck JP, Ronquist F. 2001. MRBAYES: Bayesian inference of phylogenetic trees. Bioinformatics 17(8):754-5.

28. Gardner SN, Slezak T, Hall BG. 2015. kSNP3.0: SNP detection and phylogenetic analysis of genomes without genome alignment or reference genome. Bioinformatics 1;31(17):2877-8 
458

459

460

461

462

463

464

465

466

467

468

469

470

471

472

473

474

475

476

477

478

479

480

481

482

483

484

485

486

487
29. Chen C, Bundschuh R. 2012. Systematic investigation of insertional and deletional RNADNA differences in the human transcriptome. BMC Genomics 13: 616

30. Knoop V. 2011. When you can't trust the DNA: RNA editing changes transcript sequences. Cell Mol Life Sci 68: 567-586

31. Zeng WH, Liao SC, Chang CC. 2007. Identification of RNA editing sites in chloroplast transcripts of Phalaenopsis aphrodite and comparative analysis with those of other seed plants. Plant Cell Physiol 48: 362-368

32. Luo J, Hou BW, Niu ZT, Liu W, Xue QY, Ding XY. 2014. Comparative chloroplast genomes of photosynthetic orchids: insights into evolution of the Orchidaceae and development of molecular markers for phylogenetic applications. PLoS One 9(6):e99016

33. Zhitao N, Shuying Z, Jiajia P, Ludan L, Jing S, Xiaoyu D. 2017. Comparative analysis of Dendrobium plastomes and utility of plastomic mutational hotspots. Sci Rep. 7(1):2073

34. Wang RJ, Cheng CL, Chang CC, Wu CL, Su TM, Chaw SM. 2008. Dynamics and evolution of the inverted repeat-large single copy junctions in the chloroplast genomes of monocots. BMC Evolutionary Biology 8:36

35. Li R, Ma PF, Wen J, Yi TS. 2013. Complete sequencing of five araliaceae chloroplast genomes and the phylogenetic implications. PLoS One 8(10):e78568

36. Yang M, Zhang X, Liu G, Yin Y, Chen K, Yun Q, Zhao D, Al-Mssallem IS, Yu J. 2010. The complete chloroplast genome sequence of date palm (Phoenix dactylifera L.). PLoS One 5: e12762

37. Goulding SE, Olmstead RG, Morden CW, Wolfe KH. 1996. Ebb and flow of the chloroplast inverted repeat. Mol Gen Genet 252: 195-206

38. SV Muse, BS Gaut. (1994) A likelihood approach for comparing synonymous and nonsynonymous nucleotide substitution rates, with application to the chloroplast genome. Mol Biol Evol 11:715-724.

39. Felsenstein J. (1981). Evolutionary trees from DNA sequences: a maximum likelihood approach. J. Molecular Evolution 17:368-376.

40. Kosakovsky Pond, S. L., and Frost, S. D. W. (2005) Not So Different After All: A Comparison of Methods for Detecting Amino Acid Sites Under Selection . Mol Biol Evol 22:1208-1222. 
488 41. Suzuki Y, Gojobori T. (1999) A method for detecting positive selection at single amino $489 \quad$ acid sites. Mol Biol Evol 16:1315-28.

490

491

492 
494 Figure Legends

495 Figure 1. Gene map of Dendrobium nobile chloroplast genome from Northeast India. Genes

496 shown inside the circle are transcribed clockwise, and those outside are transcribed

497 anticlockwise. Color coding indicates genes of different functional groups. A pair of inverted

498 repeats (IRA and IRB) separate the genome into LSC and SSC regions.

499

500 Figure 2. Whole chloroplast genome alignment of 38 orchid species.

501 The whole chloroplast genome alignment includes 34 Dendrobium species and 4 species from

502 the genus Goodyera as outgroup. Each genome's panel contains its name, sequence coordinates

503 and a black coloured horizontal centre line with coloured block outlines appearing above and

504 below it. Each block represents homology with the genes, internally free from genomic

505 rearrangement, connected by lines to similarly coloured blocks depicting comparative homology

506 across genomes.

507

508 Figure 3. Comparison of the borders of LSC, SSC and IR regions across Dendrobium 509 chloroplast genomes.

510

511 Figure 4. SSR distribution among different Dendrobium plastomes. The SSR were

512 determined in MISA per scripts based on the comparison between plastomes of each tested

513 Dendrobium species and D. nobile. Histograms with different color codes indicate the numbers

514 of SSRs. The minimum number (thresholds) of SSRs was set as 10, 5, 4, 3, and 3 for mono-, di-,

515 tri-, tetra-, and penta-nucleotides SSRs, respectively.

516

517 Figure 5. Phylogenetic tree based on bayesian inference from the whole genome alignment

518 matrix of Dendrobium chloroplast genomes. The tree yielded monophyletic groupings of the

519 genus Dendrobium and Goodyera species emerged as outgroup with a separate clade. Posterior

520 probability/bootstrap values are indicated on the internal nodes, which are highly supportive of

521 the overall tree topology.

522

523 Figure 6. Alignment free phylogenetic tree reconstruction based on SNP identification. The

524 optimum kmer size for the dataset is determined that calculates FCK, a measure of diversity of 
525 sequences in the dataset (Kchooser) and a consensus of the equally most parsimonious trees are 526 reported. The numbers at the nodes indicate the number of SNPs that are present in all of the 527 descendants of that node and absent in others. The numbers within parentheses at the tips 528 indicate the number of SNPs unique to each particular species. 


\section{Figure 1}

Gene map of Dendrobium nobile chloroplast genome from Northeast India

Genes shown inside the circle are transcribed clockwise, and those outside are transcribed anticlockwise. Color coding indicates genes of different functional groups. A pair of inverted repeats (IRA and IRB) separate the genome into LSC and SSC regions. 


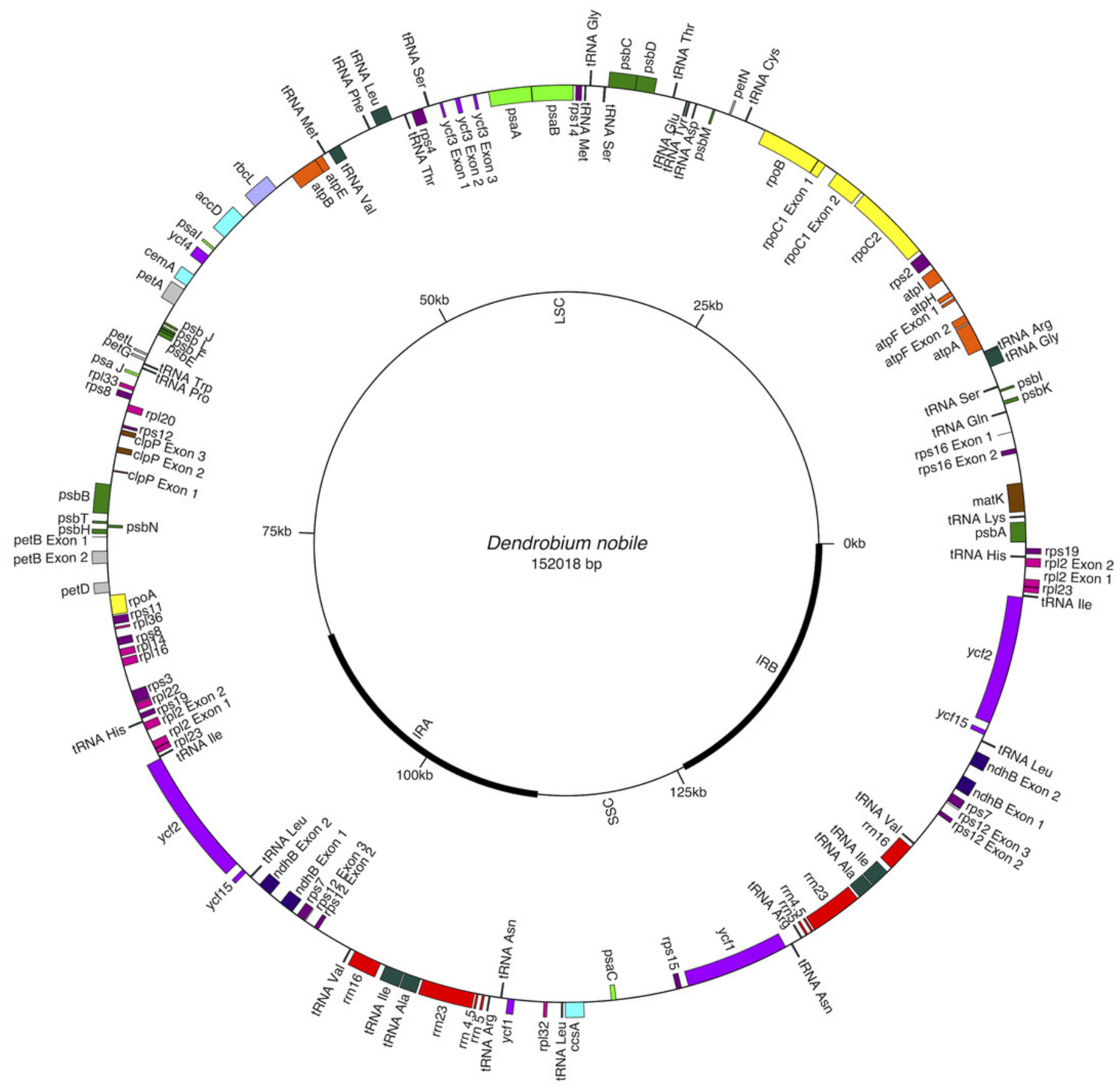




\section{Figure 2}

Whole chloroplast genome alignment of 38 orchid species.

The whole chloroplast genome alignment includes 34 Dendrobium species and 4 species from the genus Goodyera as outgroup. Each genome's panel contains its name, sequence coordinates and a black coloured horizontal centre line with coloured block outlines appearing above and below it. Each block represents homology with the genes, internally free from genomic rearrangement, connected by lines to similarly coloured blocks depicting comparative homology across genomes. 


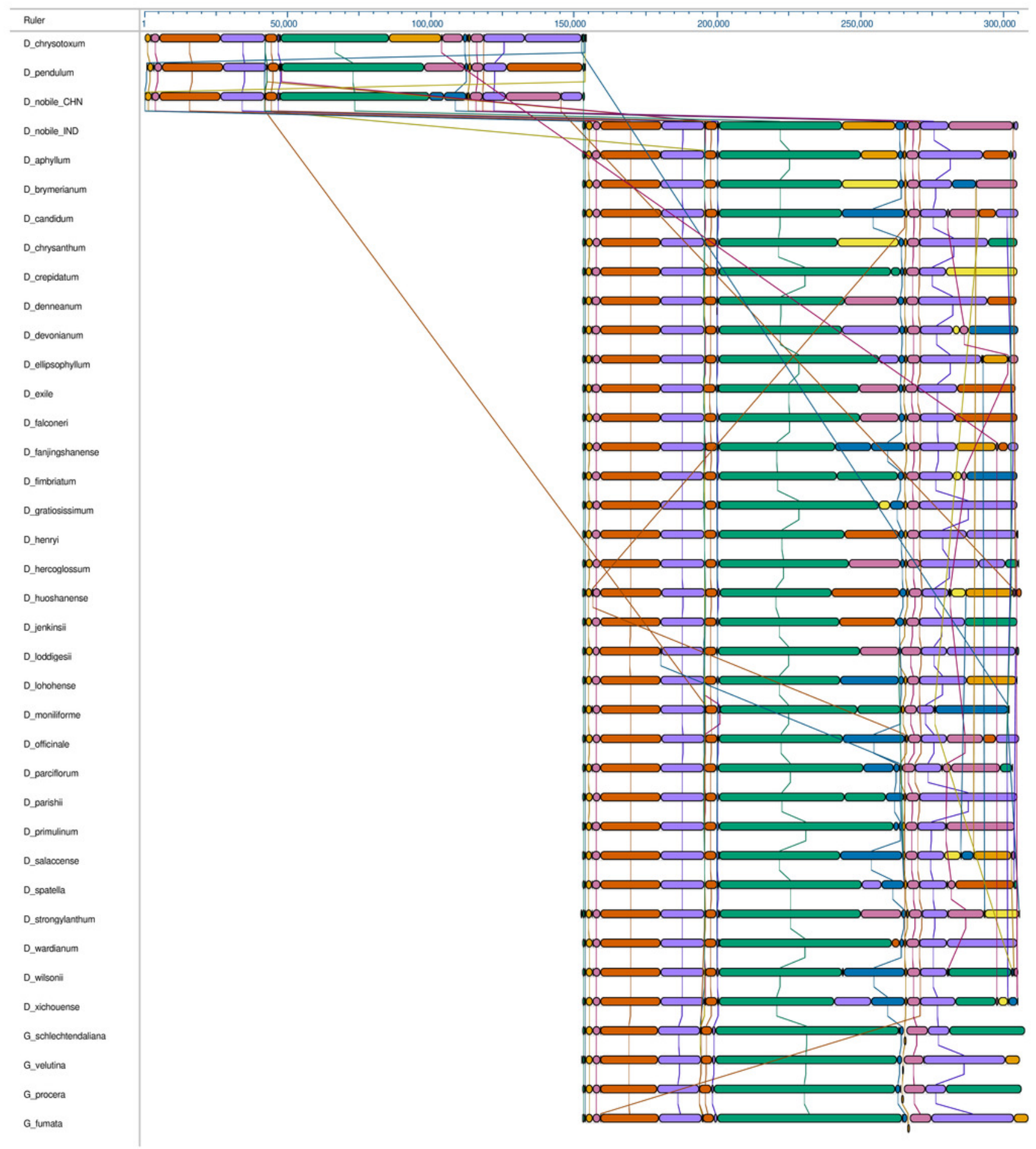


Figure 3

Comparison of the borders of LSC, SSC and IR regions across Dendrobium chloroplast genomes 
Figure 4

SSR distribution among different Dendrobium plastomes.

The SSR were determined in MISA per scripts based on the comparison between plastomes of each tested Dendrobium species and $D$. nobile. Histograms with different color codes indicate the numbers of SSRs. The minimum number (thresholds) of SSRs was set as 10, 5, 4, 3, and 3 for mono-,di-, tri-, tetra-, and penta-nucleotides SSRs, respectively. 
Distribution of SSRS

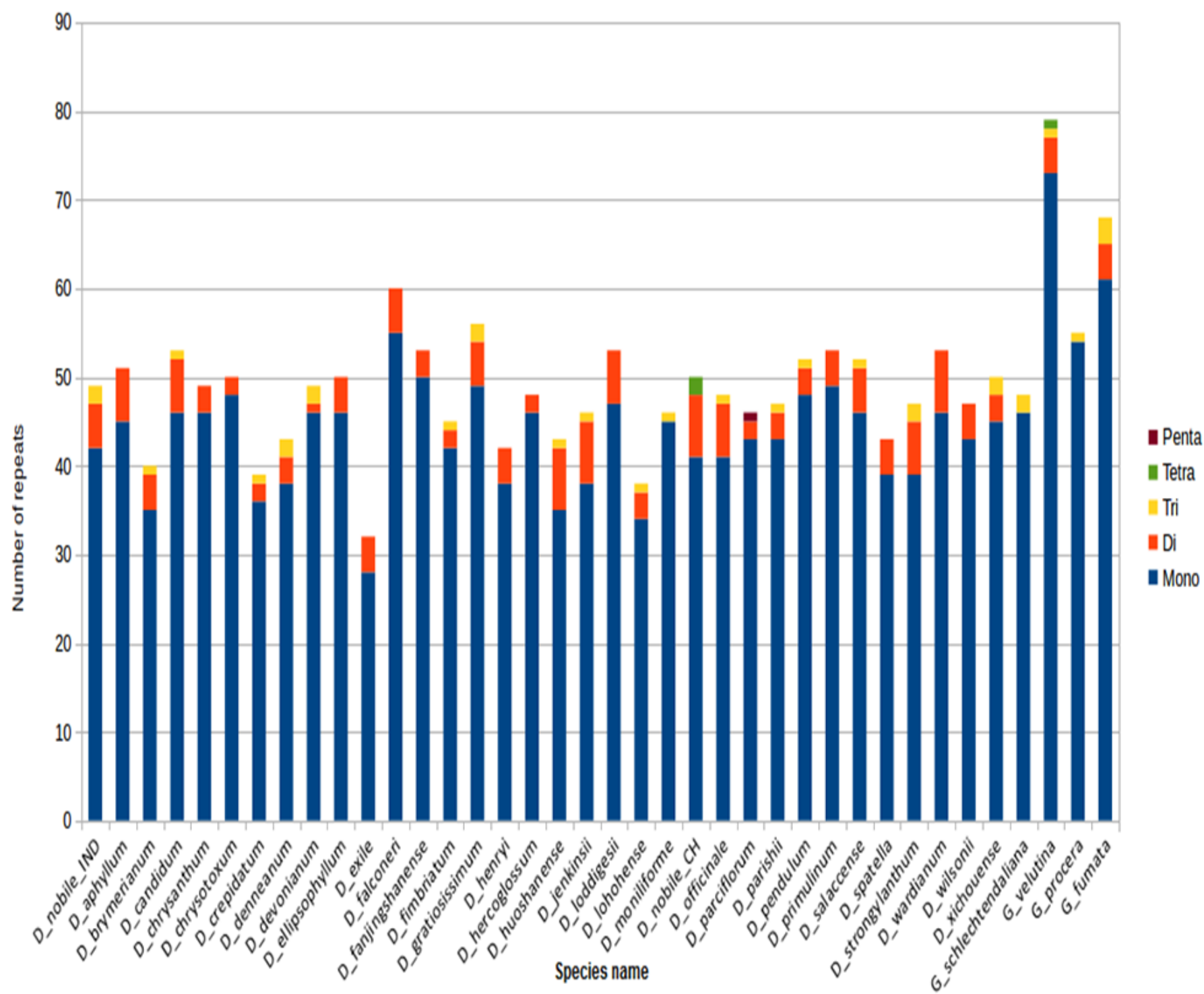


Figure 5

Phylogenetic tree based on bayesian inference from the whole genome alignment matrix of Dendrobium chloroplast genomes

The tree yielded monophyletic groupings of the genus Dendrobium and Goodyera species emerged as outgroup with a separate clade. Posterior probability/bootstrap values are indicated on the internal nodes, which are highly supportive of the overall tree topology.

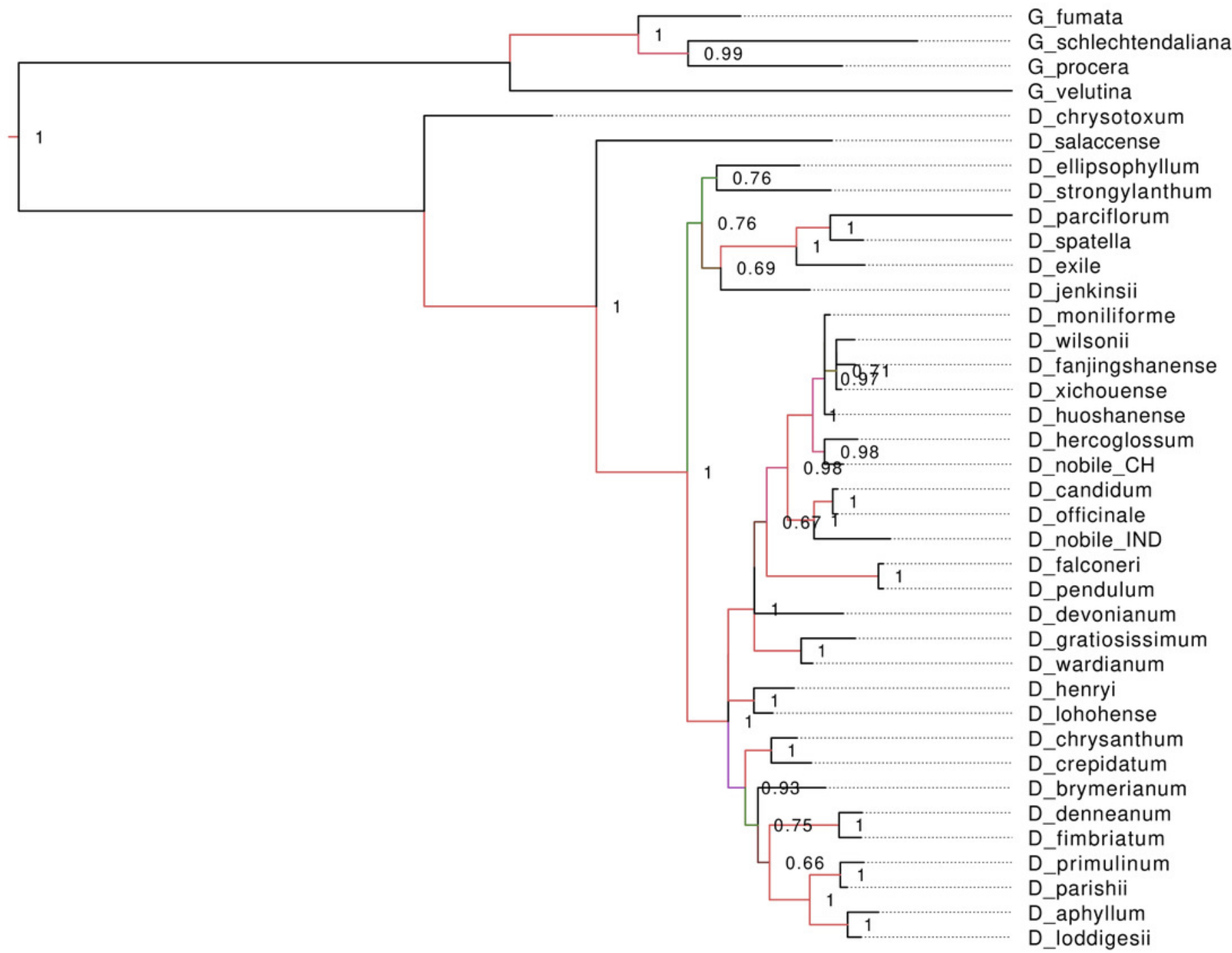


Figure 6

Alignment free phylogenetic tree reconstruction based on SNP identification

The optimum kmer size for the dataset is determined that calculates FCK, a measure of diversity of sequences in the dataset (Kchooser) and a consensus of the equally most parsimonious trees are reported. The numbers at the nodes indicate the number of SNPs that are present in all of the descendants of that node and absent in others. The numbers within parentheses at the tips indicate the number of SNPs unique to each particular species.

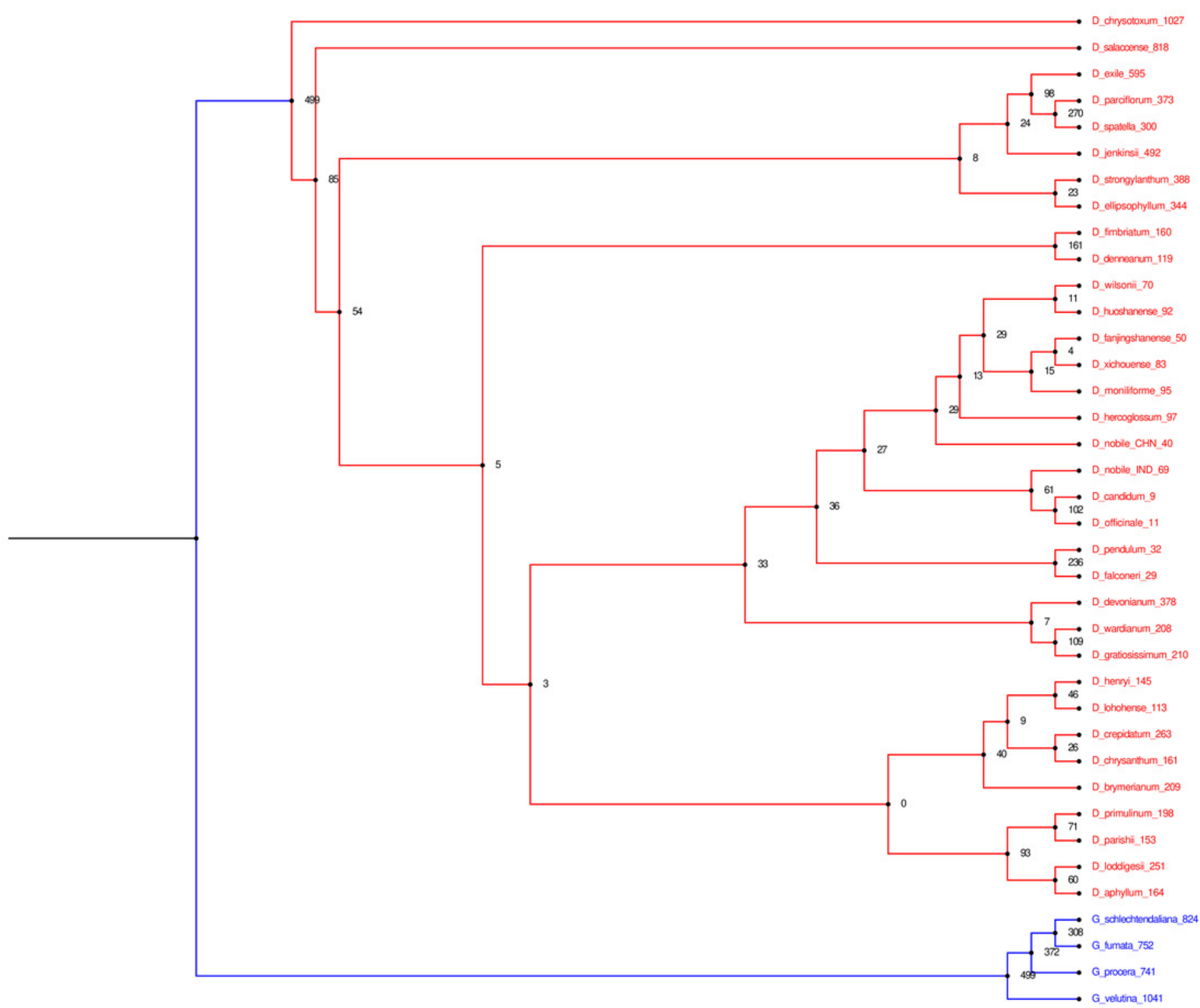




\section{Table $\mathbf{1}$ (on next page)}

RNA editing sites predicted in Dendrobium nobile chloroplast genome

D. nobile cp genome was BLAST aligned against reference datasets of Nicotiana tabacum, Oryza sativa Japonica Group, Phalaenopsis aphrodite subsp. Formosana, Physcomitrella patens subsp. Patens and Zea mays. Threshold for congruent prediction of RNA editing sites from the reference taxa was set to $<$ !--[if !msEquation]--> <!--[endif]-->3 (Count) and 75\% (Percentage of prevalence). Count is in the form of (number of reference taxa against which editing site found) / (number of taxa with the homologous site). 
Table PRAA editing sites predicted in Dendrobium nobileg chloroplastgenome, along with its GO annotations.

\begin{tabular}{|c|c|c|c|c|c|c|c|c|c|c|}
\hline Gene & GO IDs & $\begin{array}{c}\text { GO slim } \\
\text { Annotation }\end{array}$ & $\begin{array}{l}\text { Nucleotide } \\
\text { Position }\end{array}$ & $\begin{array}{c}\text { Amino } \\
\text { Acid } \\
\text { Position }\end{array}$ & $\begin{array}{c}\text { Triplet } \\
\text { position } \\
\text { within } \\
\text { codon }\end{array}$ & $\begin{array}{c}\text { Base } \\
\text { Conversion }\end{array}$ & $\begin{array}{l}\text { Codon } \\
\text { change }\end{array}$ & $\begin{array}{l}\text { Amino Acid } \\
\text { Conversion }\end{array}$ & Count & $\begin{array}{l}\text { Percentage of } \\
\text { Prevalence }\end{array}$ \\
\hline \multirow{3}{*}{ matK } & F: GO:0005198 & $\begin{array}{l}\text { F: structural } \\
\text { molecule activity }\end{array}$ & \multirow{3}{*}{1258} & \multirow{2}{*}{420} & \multirow{2}{*}{1} & \multirow{2}{*}{$\mathrm{C} \rightarrow \mathrm{U}$} & \multirow{2}{*}{$\begin{array}{c}\mathrm{CAC} \rightarrow \mathrm{UA} \\
\mathrm{C}\end{array}$} & \multirow{2}{*}{$\mathrm{H} \rightarrow \mathrm{Y}$} & \multirow{2}{*}{$4 / 5$} & \multirow{2}{*}{80} \\
\hline & P: GO:0006412 & P: translation & & & & & & & & \\
\hline & $\begin{array}{l}\text { C: GO:0005840; } \\
\text { GO:0009507 }\end{array}$ & $\begin{array}{l}\text { C: ribosome; } \\
\text { chloroplast }\end{array}$ & & 305 & 1 & $\mathrm{C} \rightarrow \mathrm{U}$ & $\underset{\mathrm{U}}{\mathrm{CAU} \rightarrow \mathrm{UA}}$ & $\mathrm{H} \rightarrow \mathrm{Y}$ & $4 / 5$ & 80 \\
\hline \multirow{3}{*}{ rps 16} & $\begin{array}{l}\text { F: GO:0000166; } \\
\text { GO:0005215 }\end{array}$ & $\begin{array}{l}\text { F: nucleotide } \\
\text { binding; } \\
\text { transporter } \\
\text { activity }\end{array}$ & \multirow{3}{*}{143} & \multirow{3}{*}{48} & \multirow{3}{*}{2} & \multirow{3}{*}{$\mathrm{C} \rightarrow \mathrm{U}$} & \multirow{3}{*}{$\begin{array}{c}\mathrm{UCA} \rightarrow \mathrm{UU} \\
\mathrm{A}\end{array}$} & \multirow{3}{*}{$\mathrm{S} \rightarrow \mathrm{L}$} & \multirow{3}{*}{$4 / 4$} & \multirow{3}{*}{100} \\
\hline & $\begin{array}{l}\text { P: GO:0006139; } \\
\text { GO:0006810; } \\
\text { GO:0009058 }\end{array}$ & $\begin{array}{l}\text { P: nucleobase- } \\
\text { containing } \\
\text { compound } \\
\text { metabolic } \\
\text { process; } \\
\text { transport; } \\
\text { biosynthetic } \\
\text { process; }\end{array}$ & & & & & & & & \\
\hline & $\begin{array}{l}\text { C: GO:0009507; } \\
\text { GO:0009579; } \\
\text { GO:0016020 }\end{array}$ & $\begin{array}{l}\text { C: chloroplast; } \\
\text { thylakoid; } \\
\text { membrane }\end{array}$ & & & & & & & & \\
\hline $\operatorname{atpA}$ & $\begin{array}{l}\text { F: GO:0000166; } \\
\text { GO:0005215 }\end{array}$ & $\begin{array}{l}\text { F: nucleotide } \\
\text { binding; } \\
\text { transporter } \\
\text { activity }\end{array}$ & 773 & 258 & 2 & $\mathrm{C} \rightarrow \mathrm{U}$ & $\begin{array}{c}\mathrm{UCA} \rightarrow \mathrm{UU} \\
\mathrm{A}\end{array}$ & $\mathrm{S} \rightarrow \mathrm{L}$ & $5 / 5$ & 100 \\
\hline
\end{tabular}




\begin{tabular}{|c|c|c|c|c|c|c|c|c|c|c|}
\hline & $\begin{array}{l}\text { P: GO:0006139; } \\
\text { GO:0006810; } \\
\text { GO:0009058 }\end{array}$ & $\begin{array}{l}\text { P: nucleobase- } \\
\text { containing } \\
\text { compound } \\
\text { metabolic } \\
\text { process; } \\
\text { transport; } \\
\text { biosynthetic } \\
\text { process }\end{array}$ & & & & & & & & \\
\hline & $\begin{array}{l}\text { C: GO:0009507; } \\
\text { GO:0009579; } \\
\text { GO:0016020 }\end{array}$ & $\begin{array}{l}\text { C: chloroplast; } \\
\text { thylakoid; } \\
\text { membrane }\end{array}$ & & & & & & & & \\
\hline \multirow{3}{*}{$\operatorname{atpF}$} & F: GO:0005215 & $\begin{array}{l}\text { F: transporter } \\
\text { activity }\end{array}$ & \multirow{3}{*}{92} & \multirow{3}{*}{31} & \multirow{3}{*}{2} & \multirow{3}{*}{$\mathrm{C} \rightarrow \mathrm{U}$} & \multirow{3}{*}{$\begin{array}{c}\mathrm{CCA} \rightarrow \mathrm{CU} \\
\mathrm{A}\end{array}$} & \multirow{3}{*}{$\mathrm{P} \rightarrow \mathrm{L}$} & \multirow{3}{*}{$5 / 5$} & \multirow{3}{*}{10} \\
\hline & $\begin{array}{l}\text { P: GO:0006139; } \\
\text { GO:0006810; } \\
\text { GO:0009058 }\end{array}$ & $\begin{array}{l}\text { P: nucleobase- } \\
\text { containing } \\
\text { compound } \\
\text { metabolic } \\
\text { process; } \\
\text { transport; } \\
\text { biosynthetic } \\
\text { process }\end{array}$ & & & & & & & & \\
\hline & $\begin{array}{l}\text { C: GO:0009507; } \\
\text { GO:0009579; } \\
\text { GO:0016020 }\end{array}$ & $\begin{array}{l}\text { C: chloroplast; } \\
\text { thylakoid; } \\
\text { membrane }\end{array}$ & & & & & & & & \\
\hline \multirow[b]{2}{*}{ atpI } & F: GO:0005215 & $\begin{array}{l}\text { F: transporter } \\
\text { activity }\end{array}$ & 629 & 210 & 2 & $\mathrm{C} \rightarrow \mathrm{U}$ & $\begin{array}{c}\mathrm{UCA} \rightarrow \mathrm{UU} \\
\mathrm{A}\end{array}$ & $\mathrm{S} \rightarrow \mathrm{L}$ & $5 / 5$ & 100 \\
\hline & $\begin{array}{l}\text { P: GO:0006139; } \\
\text { GO:0006810; } \\
\text { GO:0009058 }\end{array}$ & $\begin{array}{l}\text { P: nucleobase- } \\
\text { containing } \\
\text { compound } \\
\text { metabolic } \\
\text { process; } \\
\text { transport; } \\
\text { biosynthetic } \\
\text { process }\end{array}$ & 428 & 143 & 2 & $\mathrm{C} \rightarrow \mathrm{U}$ & $\underset{\mathrm{U}}{\mathrm{CCU} \rightarrow \mathrm{CU}}$ & $\mathrm{P} \rightarrow \mathrm{L}$ & $5 / 5$ & 100 \\
\hline
\end{tabular}




\begin{tabular}{|c|c|c|c|c|c|c|c|c|c|c|}
\hline & $\begin{array}{l}\text { C: GO:0005886; } \\
\text { GO:0009507; } \\
\text { GO:0009579 }\end{array}$ & $\begin{array}{l}\text { C: plasma } \\
\text { membrane; } \\
\text { chloroplast; } \\
\text { thylakoid }\end{array}$ & & & & & & & & \\
\hline \multirow{3}{*}{ rpoC1 } & $\begin{array}{l}\text { F: GO:0003677; } \\
\text { GO:0016740 }\end{array}$ & $\begin{array}{l}\text { F: DNA binding; } \\
\text { transferase } \\
\text { activity }\end{array}$ & 617 & 206 & 2 & $\mathrm{C} \rightarrow \mathrm{U}$ & $\begin{array}{c}\mathrm{UCG} \rightarrow \mathrm{UU} \\
\mathrm{G}\end{array}$ & $\mathrm{S} \rightarrow \mathrm{L}$ & $5 / 5$ & 100 \\
\hline & $\begin{array}{l}\text { P: GO:0006139; } \\
\text { GO:0009058 }\end{array}$ & $\begin{array}{l}\text { P: nucleobase- } \\
\text { containing } \\
\text { compound } \\
\text { metabolic } \\
\text { process; } \\
\text { biosynthetic } \\
\text { process } \\
\end{array}$ & 488 & 163 & 2 & $\mathrm{C} \rightarrow \mathrm{U}$ & $\begin{array}{c}\mathrm{UCA} \rightarrow \mathrm{UU} \\
\mathrm{A}\end{array}$ & $\mathrm{S} \rightarrow \mathrm{L}$ & $5 / 5$ & 100 \\
\hline & C: GO:0009507 & C: chloroplast & $\begin{array}{l}182 \\
41\end{array}$ & $\begin{array}{l}61 \\
14\end{array}$ & 2 & $\begin{array}{l}\mathrm{C} \rightarrow \mathrm{U} \\
\mathrm{C} \rightarrow \mathrm{U}\end{array}$ & $\begin{array}{c}\mathrm{UCU} \rightarrow \mathrm{UU} \\
\mathrm{U} \\
\mathrm{CCA} \rightarrow \mathrm{CU} \\
\mathrm{A} \\
\end{array}$ & $\begin{array}{l}\mathrm{S} \rightarrow \mathrm{F} \\
\mathrm{P} \rightarrow \mathrm{L}\end{array}$ & $\begin{array}{l}5 / 5 \\
5 / 5\end{array}$ & $\begin{array}{l}100 \\
100\end{array}$ \\
\hline \multirow{5}{*}{ rpoB } & $\begin{array}{l}\text { F: GO:0003677; } \\
\text { GO:0016740 }\end{array}$ & $\begin{array}{l}\text { F: DNA binding; } \\
\text { transferase } \\
\text { activity }\end{array}$ & $\begin{array}{l}2426 \\
623\end{array}$ & 809 & 2 & $\mathrm{C} \rightarrow \mathrm{U}$ & $\begin{array}{c}\mathrm{UCA} \rightarrow \mathrm{UU} \\
\mathrm{A} \\
\mathrm{CCG} \rightarrow \mathrm{CU} \\
\mathrm{G}\end{array}$ & $\mathrm{S} \rightarrow \mathrm{L}$ & $4 / 5$ & 80 \\
\hline & $\begin{array}{l}\text { P: GO:0006139; } \\
\text { GO:0009058 }\end{array}$ & $\begin{array}{l}\text { P: nucleobase- } \\
\text { containing } \\
\text { compound } \\
\text { metabolic } \\
\text { process; } \\
\text { biosynthetic } \\
\text { process }\end{array}$ & 566 & 189 & 2 & $\mathrm{C} \rightarrow \mathrm{U}$ & $\begin{array}{c}\mathrm{UCG} \rightarrow \mathrm{UU} \\
\mathrm{G}\end{array}$ & $\mathrm{S} \rightarrow \mathrm{L}$ & $5 / 5$ & 100 \\
\hline & & & 551 & 184 & 2 & $\mathrm{C} \rightarrow \mathrm{U}$ & $\begin{array}{c}\mathrm{UCA} \rightarrow \mathrm{UU} \\
\mathrm{A}\end{array}$ & $\mathrm{S} \rightarrow \mathrm{L}$ & $5 / 5$ & 100 \\
\hline & C: GO:0009507 & C: chloroplast & 473 & 158 & 2 & $\mathrm{C} \rightarrow \mathrm{U}$ & $\begin{array}{c}\mathrm{UCG} \rightarrow \mathrm{UU} \\
\mathrm{G}\end{array}$ & $\mathrm{S} \rightarrow \mathrm{L}$ & $5 / 5$ & 100 \\
\hline & & & 338 & 113 & 2 & $\mathrm{C} \rightarrow \mathrm{U}$ & $\begin{array}{c}\mathrm{UCU} \rightarrow \mathrm{UU} \\
\mathrm{U}\end{array}$ & $\mathrm{S} \rightarrow \mathrm{F}$ & $5 / 5$ & 100 \\
\hline
\end{tabular}




\begin{tabular}{|c|c|c|c|c|c|c|c|c|c|c|}
\hline \multirow{3}{*}{ rps14 } & $\begin{array}{l}\text { F: GO:0003723; } \\
\text { GO:0005198 }\end{array}$ & $\begin{array}{l}\text { F: RNA binding; } \\
\text { structural } \\
\text { molecule activity }\end{array}$ & \multirow{3}{*}{149} & \multirow{3}{*}{50} & \multirow{3}{*}{2} & \multirow{3}{*}{$\mathrm{C} \rightarrow \mathrm{U}$} & \multirow{3}{*}{$\begin{array}{c}\mathrm{CCA} \rightarrow \mathrm{CU} \\
\mathrm{A}\end{array}$} & \multirow{3}{*}{$\mathrm{P} \rightarrow \mathrm{L}$} & \multirow{3}{*}{$5 / 5$} & \multirow{3}{*}{100} \\
\hline & $\begin{array}{l}\text { P: GO:0006091; } \\
\text { GO:0006412; } \\
\text { GO:0015979 }\end{array}$ & $\begin{array}{l}\text { P: generation of } \\
\text { precursor } \\
\text { metabolites and } \\
\text { energy; } \\
\text { translation; } \\
\text { photosynthesis }\end{array}$ & & & & & & & & \\
\hline & $\begin{array}{l}\text { C: GO:0009507; } \\
\text { GO:0009579; } \\
\text { GO:0016020; } \\
\text { GO:0005840 }\end{array}$ & $\begin{array}{l}\text { C: chloroplast; } \\
\text { thylakoid; } \\
\text { membrane; } \\
\text { ribosome }\end{array}$ & & & & & & & & \\
\hline \multirow{3}{*}{$y c f 3$} & F: GO:0005515 & $\mathrm{F}$ : protein binding & \multirow{2}{*}{$\begin{array}{l}191 \\
185\end{array}$} & \multirow{2}{*}{$\begin{array}{l}64 \\
62\end{array}$} & \multirow{2}{*}{$\begin{array}{l}2 \\
2\end{array}$} & \multirow{2}{*}{$\begin{array}{l}\mathrm{C} \rightarrow \mathrm{U} \\
\mathrm{C} \rightarrow \mathrm{U}\end{array}$} & \multirow{3}{*}{$\begin{array}{c}\mathrm{CCA} \rightarrow \mathrm{CU} \\
\mathrm{A} \\
\mathrm{ACG} \rightarrow \mathrm{AU} \\
\mathrm{G} \\
\begin{array}{l}\mathrm{UCU} \rightarrow \mathrm{UU} \\
\mathrm{U}\end{array}\end{array}$} & \multirow{2}{*}{$\begin{array}{l}\mathrm{P} \rightarrow \mathrm{L} \\
\mathrm{T} \rightarrow \mathrm{M}\end{array}$} & \multirow{2}{*}{$\begin{array}{l}5 / 5 \\
5 / 5\end{array}$} & \multirow{2}{*}{$\begin{array}{l}100 \\
100\end{array}$} \\
\hline & P: GO:0015979 & P: photosynthesis & & & & & & & & \\
\hline & $\begin{array}{l}\text { C: GO:0009507; } \\
\text { GO:0009579; } \\
\text { GO:0016020 }\end{array}$ & $\begin{array}{l}\text { C: chloroplast; } \\
\text { thylakoid; } \\
\text { membrane }\end{array}$ & 44 & 15 & 2 & $\mathrm{C} \rightarrow \mathrm{U}$ & & $\mathrm{S} \rightarrow \mathrm{F}$ & $5 / 5$ & 100 \\
\hline \multirow[b]{2}{*}{ atpB } & $\begin{array}{l}\text { F: GO:0000166; } \\
\text { GO:0005215 }\end{array}$ & $\begin{array}{l}\text { F: nucleotide } \\
\text { binding; } \\
\text { transporter } \\
\text { activity }\end{array}$ & \multirow[b]{2}{*}{1184} & \multirow[b]{2}{*}{395} & \multirow[b]{2}{*}{2} & \multirow[b]{2}{*}{$\mathrm{C} \rightarrow \mathrm{U}$} & \multirow[b]{2}{*}{$\begin{array}{c}\mathrm{UCA} \rightarrow \mathrm{UU} \\
\mathrm{A}\end{array}$} & \multirow[b]{2}{*}{$\mathrm{S} \rightarrow \mathrm{L}$} & \multirow[b]{2}{*}{$5 / 5$} & \multirow[b]{2}{*}{100} \\
\hline & $\begin{array}{l}\text { P: GO:0006139; } \\
\text { GO:0006810; } \\
\text { GO:0009058 }\end{array}$ & $\begin{array}{l}\text { P: nucleobase- } \\
\text { containing } \\
\text { compound } \\
\text { metabolic } \\
\text { process; } \\
\text { transport; } \\
\text { biosynthetic } \\
\text { process }\end{array}$ & & & & & & & & \\
\hline
\end{tabular}




\begin{tabular}{|c|c|c|c|c|c|c|c|c|c|c|}
\hline & $\begin{array}{l}\text { C: GO:0009507; } \\
\text { GO:0009579; } \\
\text { GO:0016020 }\end{array}$ & $\begin{array}{l}\text { C: chloroplast; } \\
\text { thylakoid; } \\
\text { membrane }\end{array}$ & & & & & & & & \\
\hline \multirow{3}{*}{$\operatorname{accD}$} & $\begin{array}{l}\text { F: GO:0000166; } \\
\text { GO:0016740 }\end{array}$ & $\begin{array}{l}\text { F: nucleotide } \\
\text { binding; } \\
\text { transporter } \\
\text { activity }\end{array}$ & \multirow{2}{*}{$\begin{array}{r}1184 \\
1412\end{array}$} & 395 & 2 & $\mathrm{C} \rightarrow \mathrm{U}$ & $\begin{array}{c}\mathrm{UCA} \rightarrow \mathrm{UU} \\
\mathrm{A}\end{array}$ & $\mathrm{S} \rightarrow \mathrm{L}$ & $4 / 4$ & 100 \\
\hline & $\begin{array}{l}\text { P: GO:0006139; } \\
\text { GO:0006629; } \\
\text { GO:0009058 }\end{array}$ & $\begin{array}{l}\text { P: nucleobase- } \\
\text { containing } \\
\text { compound } \\
\text { metabolic } \\
\text { process; lipid } \\
\text { metabolic } \\
\text { process; } \\
\text { biosynthetic } \\
\text { process }\end{array}$ & & 471 & 2 & $\mathrm{C} \rightarrow \mathrm{U}$ & $\begin{array}{c}\mathrm{CCA} \rightarrow \mathrm{CU} \\
\mathrm{A}\end{array}$ & $\mathrm{P} \rightarrow \mathrm{L}$ & $3 / 3$ & 100 \\
\hline & C: GO:0009507 & C: chloroplast & 1430 & 477 & 2 & $\mathrm{C} \rightarrow \mathrm{U}$ & $\begin{array}{c}\mathrm{CCU} \rightarrow \mathrm{CU} \\
\mathrm{U}\end{array}$ & $\mathrm{P} \rightarrow \mathrm{L}$ & $3 / 3$ & 100 \\
\hline \multirow[b]{2}{*}{ psaI } & P: GO:0015979; & P: photosynthesis & \multirow[b]{2}{*}{80} & \multirow[b]{2}{*}{27} & \multirow[b]{2}{*}{2} & \multirow[b]{2}{*}{$\mathrm{C} \rightarrow \mathrm{U}$} & \multirow[b]{2}{*}{$\underset{\mathrm{U}}{\mathrm{UCU} \rightarrow \mathrm{UU}}$} & \multirow[b]{2}{*}{$\mathrm{S} \rightarrow \mathrm{F}$} & \multirow[b]{2}{*}{$5 / 5$} & \multirow[b]{2}{*}{10} \\
\hline & $\begin{array}{l}\text { C: GO:0009507; } \\
\text { GO:0009579; } \\
\text { GO:0016020 }\end{array}$ & $\begin{array}{l}\text { C: chloroplast; } \\
\text { thylakoid; } \\
\text { membrane }\end{array}$ & & & & & & & & \\
\hline \multirow[b]{2}{*}{$\mathrm{psbF}$} & $\begin{array}{l}\text { F: GO:0003824; } \\
\text { GO:0005488 }\end{array}$ & $\begin{array}{l}\text { F: catalytic } \\
\text { activity; binding }\end{array}$ & \multirow[b]{2}{*}{77} & \multirow[b]{2}{*}{26} & \multirow[b]{2}{*}{2} & \multirow[b]{2}{*}{$\mathrm{C} \rightarrow \mathrm{U}$} & \multirow[b]{2}{*}{$\underset{\mathrm{U}}{\mathrm{UCU} \rightarrow \mathrm{UU}}$} & \multirow[b]{2}{*}{$\mathrm{S} \rightarrow \mathrm{F}$} & \multirow[b]{2}{*}{$5 / 5$} & \multirow[b]{2}{*}{100} \\
\hline & $\begin{array}{l}\text { P: GO:0006091; } \\
\text { GO:0015979; }\end{array}$ & $\begin{array}{l}\text { P: generation of } \\
\text { precursor } \\
\text { metabolites and } \\
\text { energy; } \\
\text { photosynthesis }\end{array}$ & & & & & & & & \\
\hline
\end{tabular}




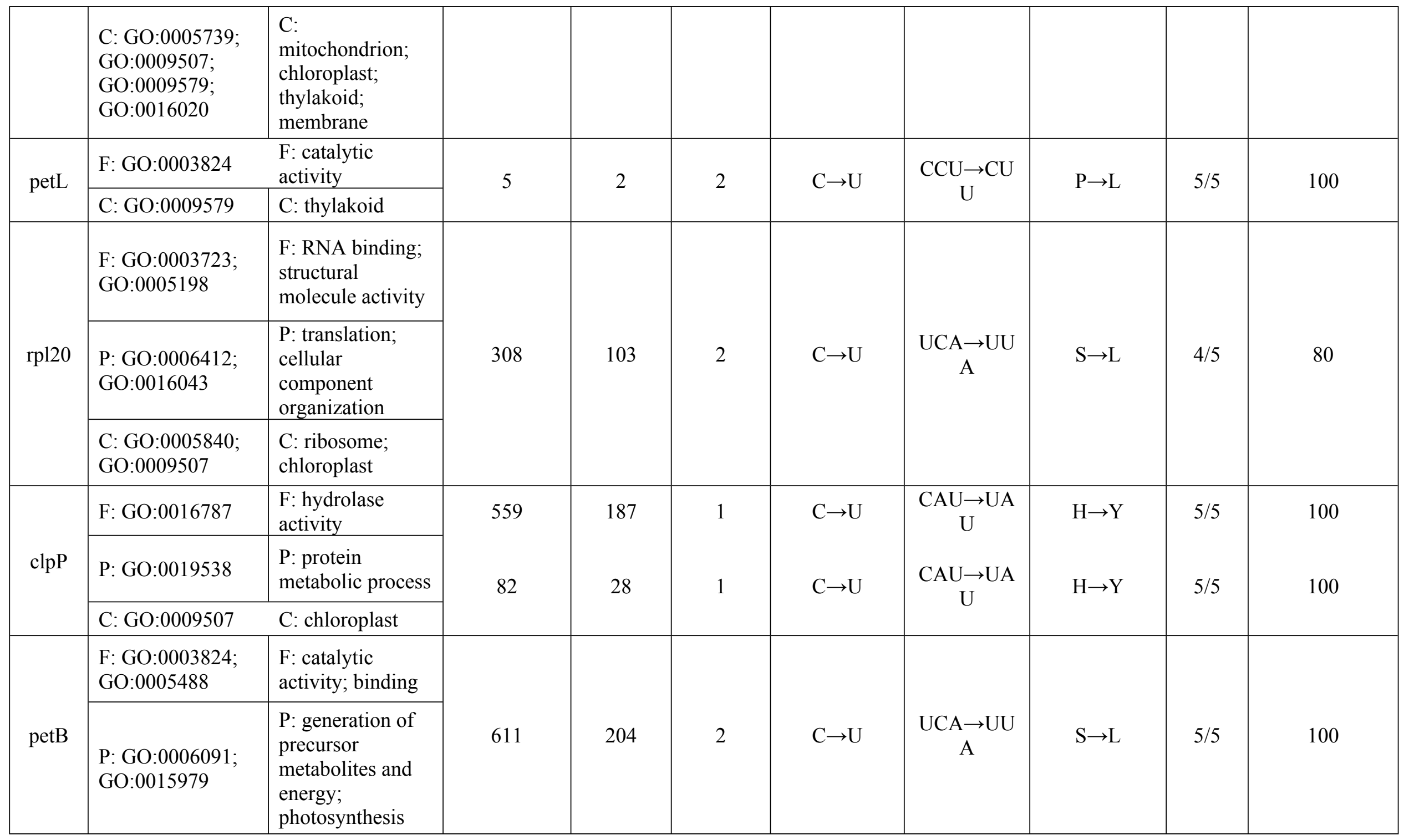




\begin{tabular}{|c|c|c|c|c|c|c|c|c|c|c|}
\hline & $\begin{array}{l}\text { C:GO:0009507; } \\
\text { GO:0009579; } \\
\text { GO:0016020 }\end{array}$ & $\begin{array}{l}\text { C: chloroplast; } \\
\text { thylakoid; } \\
\text { membrane }\end{array}$ & & & & & & & & \\
\hline \multirow{3}{*}{ rpoA } & $\begin{array}{l}\text { F: GO:0003677; } \\
\text { GO:0005515; } \\
\text { GO:0016740 }\end{array}$ & $\begin{array}{l}\text { F: DNA binding; } \\
\text { protein binding; } \\
\text { transferase } \\
\text { activity }\end{array}$ & \multirow[t]{2}{*}{830} & 277 & 2 & $\mathrm{C} \rightarrow \mathrm{U}$ & $\begin{array}{c}\mathrm{UCA} \rightarrow \mathrm{UU} \\
\mathrm{A}\end{array}$ & $\mathrm{S} \rightarrow \mathrm{L}$ & $4 / 4$ & 100 \\
\hline & $\begin{array}{l}\text { P: GO:0006139; } \\
\text { GO:0009058 }\end{array}$ & $\begin{array}{l}\text { P: nucleobase- } \\
\text { containing } \\
\text { compound } \\
\text { metabolic } \\
\text { process; } \\
\text { biosynthetic } \\
\text { process } \\
\end{array}$ & & 123 & 2 & $\mathrm{C} \rightarrow \mathrm{U}$ & $\begin{array}{c}\mathrm{UCA} \rightarrow \mathrm{UU} \\
\mathrm{A}\end{array}$ & $\mathrm{S} \rightarrow \mathrm{L}$ & $4 / 4$ & 100 \\
\hline & C: GO:0009507 & C: chloroplast & 200 & 67 & 2 & $\mathrm{C} \rightarrow \mathrm{U}$ & $\begin{array}{c}\mathrm{UCU} \rightarrow \mathrm{UU} \\
\mathrm{U}\end{array}$ & $\mathrm{S} \rightarrow \mathrm{F}$ & $3 / 4$ & 75 \\
\hline \multirow[t]{3}{*}{$\mathrm{rpl} 2$} & $\begin{array}{l}\text { F: GO:0003723; } \\
\text { GO:0005198; } \\
\text { GO:0016740 }\end{array}$ & $\begin{array}{l}\text { F: RNA binding; } \\
\text { structural } \\
\text { molecule activity; } \\
\text { transferase } \\
\text { activity }\end{array}$ & \multirow[t]{3}{*}{2} & \multirow[t]{3}{*}{1} & \multirow[t]{3}{*}{2} & \multirow[t]{3}{*}{$\mathrm{C} \rightarrow \mathrm{U}$} & \multirow{3}{*}{$\begin{array}{c}\mathrm{ACG} \rightarrow \mathrm{AU} \\
\mathrm{G}\end{array}$} & \multirow[t]{3}{*}{$\mathrm{T} \rightarrow \mathrm{M}$} & \multirow[t]{3}{*}{$5 / 5$} & \multirow[t]{3}{*}{100} \\
\hline & P: GO:0006412 & P: translation & & & & & & & & \\
\hline & $\begin{array}{l}\text { C: GO:0005840; } \\
\text { GO:0009507 }\end{array}$ & $\begin{array}{l}\text { C: ribosome; } \\
\text { chloroplast }\end{array}$ & & & & & & & & \\
\hline \multirow[b]{2}{*}{ ndhD } & $\begin{array}{l}\text { F: GO:0003824; } \\
\text { GO:0005488 }\end{array}$ & $\begin{array}{l}\text { F: catalytic } \\
\text { activity; binding }\end{array}$ & 878 & 293 & 2 & $\mathrm{C} \rightarrow \mathrm{U}$ & $\begin{array}{c}\mathrm{UCA} \rightarrow \mathrm{UU} \\
\mathrm{A}\end{array}$ & $\mathrm{S} \rightarrow \mathrm{L}$ & $4 / 4$ & 100 \\
\hline & P: GO:0006091 & $\begin{array}{l}\text { P: generation of } \\
\text { precursor } \\
\text { metabolites and } \\
\text { energy }\end{array}$ & 674 & 225 & 2 & $\mathrm{C} \rightarrow \mathrm{U}$ & $\begin{array}{c}\mathrm{UCG} \rightarrow \mathrm{UU} \\
\mathrm{G}\end{array}$ & $\mathrm{S} \rightarrow \mathrm{L}$ & $4 / 4$ & 100 \\
\hline
\end{tabular}




\begin{tabular}{|c|c|c|c|c|c|c|c|c|c|c|}
\hline & $\begin{array}{l}\text { C: GO:0009507; } \\
\text { GO:0009579; } \\
\text { GO:0016020 }\end{array}$ & $\begin{array}{l}\text { C: chloroplast; } \\
\text { thylakoid; } \\
\text { membrane }\end{array}$ & 383 & 128 & 2 & $\mathrm{C} \rightarrow \mathrm{U}$ & $\begin{array}{c}\mathrm{UCA} \rightarrow \mathrm{UU} \\
\mathrm{A}\end{array}$ & $\mathrm{S} \rightarrow \mathrm{L}$ & $4 / 4$ & 100 \\
\hline \multirow{3}{*}{ ndhA } & $\begin{array}{l}\text { F: GO:0003824; } \\
\text { GO:0005488 }\end{array}$ & $\begin{array}{l}\text { F: catalytic } \\
\text { activity; binding }\end{array}$ & \multirow{3}{*}{473} & \multirow{3}{*}{158} & \multirow{3}{*}{2} & \multirow{3}{*}{$\mathrm{C} \rightarrow \mathrm{U}$} & \multirow{3}{*}{$\begin{array}{c}\mathrm{UCA} \rightarrow \mathrm{UU} \\
\mathrm{A}\end{array}$} & \multirow{3}{*}{$\mathrm{S} \rightarrow \mathrm{L}$} & \multirow{3}{*}{$4 / 4$} & \multirow{3}{*}{100} \\
\hline & $\begin{array}{l}\text { P: GO:0006091; } \\
\text { GO:0015979 }\end{array}$ & $\begin{array}{l}\text { P: generation of } \\
\text { precursor } \\
\text { metabolites and } \\
\text { energy; } \\
\text { photosynthesis }\end{array}$ & & & & & & & & \\
\hline & $\begin{array}{l}\text { C: GO:0005886; } \\
\text { GO:0009507; } \\
\text { GO:0009579 }\end{array}$ & $\begin{array}{l}\text { C: plasma } \\
\text { membrane; } \\
\text { chloroplast; } \\
\text { thylakoid }\end{array}$ & & & & & & & & \\
\hline \multirow{8}{*}{ ndhB } & \multirow{3}{*}{$\begin{array}{l}\text { F: GO:0003824; } \\
\text { GO:0005488 }\end{array}$} & \multirow{3}{*}{$\begin{array}{l}\text { F: catalytic } \\
\text { activity; binding }\end{array}$} & 149 & 50 & 2 & $\mathrm{C} \rightarrow \mathrm{U}$ & $\begin{array}{c}\mathrm{UCA} \rightarrow \mathrm{UU} \\
\mathrm{A}\end{array}$ & $\mathrm{S} \rightarrow \mathrm{L}$ & $4 / 4$ & 100 \\
\hline & & & 467 & 156 & 2 & $\mathrm{C} \rightarrow \mathrm{U}$ & $\begin{array}{c}\mathrm{CCA} \rightarrow \mathrm{CU} \\
\mathrm{A}\end{array}$ & $\mathrm{P} \rightarrow \mathrm{L}$ & $4 / 4$ & 100 \\
\hline & & & 586 & 196 & 1 & $\mathrm{C} \rightarrow \mathrm{U}$ & $\underset{U}{\mathrm{CAU} \rightarrow \mathrm{UA}}$ & $\mathrm{H} \rightarrow \mathrm{Y}$ & $4 / 4$ & 100 \\
\hline & \multirow{3}{*}{$\begin{array}{l}\text { P: GO:0006091; } \\
\text { GO:0015979 }\end{array}$} & \multirow{3}{*}{$\begin{array}{l}\text { P: generation of } \\
\text { precursor } \\
\text { metabolites and } \\
\text { energy; } \\
\text { photosynthesis }\end{array}$} & 704 & 235 & 2 & $\mathrm{C} \rightarrow \mathrm{U}$ & $\underset{\mathrm{C}}{\mathrm{UCC} \rightarrow \mathrm{UU}}$ & $\mathrm{S} \rightarrow \mathrm{F}$ & $4 / 4$ & 100 \\
\hline & & & 737 & 246 & 2 & $\mathrm{C} \rightarrow \mathrm{U}$ & $\begin{array}{c}\mathrm{CCA} \rightarrow \mathrm{CU} \\
\mathrm{A}\end{array}$ & $\mathrm{P} \rightarrow \mathrm{L}$ & $4 / 4$ & 100 \\
\hline & & & 830 & 277 & 2 & $\mathrm{C} \rightarrow \mathrm{U}$ & $\begin{array}{c}\mathrm{UCA} \rightarrow \mathrm{UU} \\
\mathrm{A}\end{array}$ & $\mathrm{S} \rightarrow \mathrm{L}$ & $4 / 5$ & 80 \\
\hline & \multirow{2}{*}{$\begin{array}{l}\text { C: GO:0005886; } \\
\text { GO:0009507; } \\
\text { GO:0009579 }\end{array}$} & \multirow{2}{*}{$\begin{array}{l}\text { C: plasma } \\
\text { membrane; } \\
\text { chloroplast; } \\
\text { thylakoid }\end{array}$} & 836 & 279 & 2 & $\mathrm{C} \rightarrow \mathrm{U}$ & $\begin{array}{c}\mathrm{UCA} \rightarrow \mathrm{UU} \\
\mathrm{A}\end{array}$ & $\mathrm{S} \rightarrow \mathrm{L}$ & $4 / 5$ & 80 \\
\hline & & & 1481 & 494 & 2 & $\mathrm{C} \rightarrow \mathrm{U}$ & $\begin{array}{c}\mathrm{CCA} \rightarrow \mathrm{CU} \\
\mathrm{A}\end{array}$ & $\mathrm{P} \rightarrow \mathrm{L}$ & $4 / 4$ & 100 \\
\hline rpl23 & $\begin{array}{l}\text { F: GO:0003723; } \\
\text { GO:0005198 }\end{array}$ & $\begin{array}{l}\text { F: RNA binding; } \\
\text { structural } \\
\text { molecule activity }\end{array}$ & 71 & 24 & 2 & $\mathrm{C} \rightarrow \mathrm{U}$ & $\underset{\mathrm{U}}{\mathrm{UCU} \rightarrow \mathrm{UU}}$ & $\mathrm{S} \rightarrow \mathrm{F}$ & $4 / 5$ & 80 \\
\hline
\end{tabular}




\begin{tabular}{|l|l|l|l|l|l|l|l|l|}
\hline & P: GO:0006412 & P: translation & & & & & & \\
\cline { 2 - 3 } $\begin{array}{l}\text { C: GO:0005840; } \\
\text { GO: } 0009507\end{array}$ & $\begin{array}{l}\text { C: ribosome; } \\
\text { chloroplast }\end{array}$ & & & & & \\
\hline
\end{tabular}

D. nobile cp genome was BLAST aligned against reference datasets of Nicotiana tabacum, Oryza sativa Japonica Group, Phalaenopsis aphrodite subsp. Formosana, Physcomitrella patens subsp. Patens and Zea mays. Threshold for congruent prediction of 4 RNA editing sites from the reference taxa was set to $\geq 3$ (Count) and $75 \%$ (Percentage of prevalence). Count is in the form of 5 (number of reference taxa against which editing site found) / (number of taxa with the homologous site). Further the genes were exported to OMIX box, blast aligned and subsequently mapped and annotated with Gene ontology (GO) slim terms. Their 7 corresponding GO ids and annotations are shown in the table. 


\section{Table 2 (on next page)}

Summary of characteristics in chloroplast genome sequences of thirty-four Dendrobium species and four Goodyera species (taken as outgroup) 
1 Table 2. Summary of characteristics in chloroplast genome sequences of thirty-four Dendrobium 2 species and four Goodyera species (taken as outgroup).

\begin{tabular}{|c|c|c|c|c|}
\hline Organism & $\begin{array}{l}\text { Accession } \\
\text { Number }\end{array}$ & Length & $\begin{array}{l}\text { Weight } \\
\text { (single- } \\
\text { stranded) } \\
\text { Mda }\end{array}$ & $\begin{array}{l}\text { Weight } \\
\text { (double- } \\
\text { stranded) } \\
\text { Mda }\end{array}$ \\
\hline Dendrobium nobile & KX377961 & 152018 & 46.932 & 93.912 \\
\hline Dendrobium officinale & NC_024019 & 152221 & 46.995 & 94.038 \\
\hline Dendrobium strongylanthum & NC_ 027691 & 153059 & 47.256 & 94.556 \\
\hline Dendrobium huoshanense & $\mathrm{NC} 028430$ & 153188 & 47.294 & 94.635 \\
\hline Dendrobium chrysotoxum & NC_028549 & 153953 & 47.528 & 95.108 \\
\hline Dendrobium nobile (China) & NC_029456 & 153660 & 47.453 & 94.927 \\
\hline Dendrobium pendulum & NC_ 029705 & 153038 & 47.246 & 94.542 \\
\hline Dendrobium moniliforme & NC_035154 & 148778 & 45.931 & 91.911 \\
\hline Dendrobium primulinum & NC_ 035321 & 150767 & 46.545 & 93.14 \\
\hline Dendrobium aphyllum & NC_ 035322 & 151524 & 46.779 & 93.607 \\
\hline Dendrobium brymerianum & NC_035323 & 151830 & 46.873 & 93.796 \\
\hline Dendrobium denneanum & NC_ 035324 & 151565 & 46.793 & 93.633 \\
\hline Dendrobium devonianum & NC_ 035325 & 151945 & 46.909 & 93.867 \\
\hline Dendrobium falconeri & NC_035326 & 151890 & 46.891 & 93.833 \\
\hline Dendrobium gratiosissimum & NC_ 035327 & 151829 & 46.873 & 93.796 \\
\hline Dendrobium hercoglossum & NC_ 035328 & 151939 & 46.908 & 93.864 \\
\hline Dendrobium wardianum & NC 035329 & 151788 & 46.861 & 93.77 \\
\hline Dendrobium wilsonii & NC_ 035330 & 152080 & 46.951 & 93.951 \\
\hline Dendrobium crepidatum & NC_ 035331 & 151717 & 46.837 & 93.726 \\
\hline Dendrobium salaccense & NC_ 035332 & 151104 & 46.648 & 93.347 \\
\hline Dendrobium spatella & NC_ 035333 & 151829 & 46.872 & 93.796 \\
\hline Dendrobium parciflorum & NC_035334 & 150073 & 46.331 & 92.711 \\
\hline Dendrobium henryi & NC_035335 & 151850 & 46.88 & 93.809 \\
\hline Dendrobium chrysanthum & NC 035336 & 151790 & 46.861 & 93.772 \\
\hline Dendrobium jenkinsii & NC_035337 & 151717 & 46.839 & 93.726 \\
\hline Dendrobium lohohense & NC_ 035338 & 151812 & 46.868 & 93.785 \\
\hline Dendrobium parishii & NC_035339 & 151689 & 46.83 & 93.709 \\
\hline Dendrobium ellipsophyllum & NC_035340 & 152026 & 46.935 & 93.917 \\
\hline Dendrobium xichouense & NC_ 035341 & 152052 & 46.942 & 93.933 \\
\hline Dendrobium fimbriatum & NC 035342 & 151673 & 46.825 & 93.699 \\
\hline Dendrobium exile & NC_035343 & 151294 & 46.707 & 93.465 \\
\hline Dendrobium fanjingshanense & NC 035344 & 152108 & 46.96 & 93.968 \\
\hline Dendrobium candidum & NC 035745 & 152094 & 46.955 & 93.959 \\
\hline Dendrobium loddigesii & NC_036355 & 152493 & 47.077 & 94.205 \\
\hline Goodyera fumata & NC 026773 & 155643 & 48.048 & 96.151 \\
\hline Goodyera procera & NC_ 029363 & 153240 & 47.306 & 94.667 \\
\hline Goodyera schlechtendaliana & NC_029364 & 154348 & 47.648 & 95.351 \\
\hline Goodyera velutina & NC 029365 & 152692 & 47.138 & 94.328 \\
\hline
\end{tabular}




\section{Table 3 (on next page)}

Summary features of chloroplast genome sequences of thirty-four Dendrobium species and four Goodyera species 
1 Table 3. Summary features of chloroplast genome sequences of thirty-four Dendrobium species 2 and four Goodyera species

3

\begin{tabular}{|c|c|c|c|c|c|c|c|}
\hline Organism & CDS & Exon & Gene & $\begin{array}{l}\text { Misc. } \\
\text { feature }\end{array}$ & $\begin{array}{l}\text { Repeat } \\
\text { region }\end{array}$ & rRNA & tRNA \\
\hline Dendrobium nobile & 79 & 22 & 132 & 2 & 2 & 8 & 38 \\
\hline Dendrobium officinale & 76 & 0 & 129 & 0 & 0 & 8 & 38 \\
\hline $\begin{array}{l}\text { Dendrobium } \\
\text { strongylanthum }\end{array}$ & 77 & 0 & 130 & 2 & 2 & 8 & 38 \\
\hline $\begin{array}{l}\text { Dendrobium } \\
\text { huoshanense }\end{array}$ & 76 & 0 & 129 & 2 & 2 & 8 & 38 \\
\hline $\begin{array}{l}\text { Dendrobium } \\
\text { chrysotoxum }\end{array}$ & 63 & 0 & 116 & 2 & 2 & 8 & 38 \\
\hline $\begin{array}{l}\text { Dendrobium nobile } \\
\text { (China) }\end{array}$ & 77 & 0 & 130 & 2 & 2 & 8 & 38 \\
\hline Dendrobium pendulum & 76 & 0 & 129 & 2 & 2 & 8 & 38 \\
\hline $\begin{array}{l}\text { Dendrobium } \\
\text { moniliforme }\end{array}$ & 73 & 0 & 129 & 11 & 2 & 8 & 39 \\
\hline Dendrobium primulinum & 72 & 0 & 132 & 16 & 2 & 8 & 38 \\
\hline Dendrobium aphyllum & 72 & 0 & 132 & 16 & 2 & 8 & 38 \\
\hline $\begin{array}{l}\text { Dendrobium } \\
\text { brymerianum }\end{array}$ & 72 & 0 & 132 & 16 & 2 & 8 & 38 \\
\hline Dendrobium denneanum & 72 & 0 & 132 & 16 & 2 & 8 & 38 \\
\hline $\begin{array}{l}\text { Dendrobium } \\
\text { devonianum }\end{array}$ & 72 & 0 & 132 & 16 & 2 & 8 & 38 \\
\hline Dendrobium falconeri & 72 & 0 & 132 & 16 & 2 & 8 & 38 \\
\hline $\begin{array}{l}\text { Dendrobium } \\
\text { gratiosissimum }\end{array}$ & 72 & 0 & 132 & 16 & 2 & 8 & 38 \\
\hline $\begin{array}{l}\text { Dendrobium } \\
\text { hercoglossum }\end{array}$ & 72 & 0 & 132 & 16 & 2 & 8 & 38 \\
\hline Dendrobium wardianum & 71 & 0 & 131 & 16 & 2 & 8 & 38 \\
\hline Dendrobium wilsonii & 72 & 0 & 132 & 16 & 2 & 8 & 38 \\
\hline Dendrobium crepidatum & 72 & 0 & 132 & 16 & 2 & 8 & 38 \\
\hline Dendrobium salaccense & 72 & 0 & 132 & 16 & 2 & 8 & 38 \\
\hline Dendrobium spatella & 72 & 0 & 132 & 16 & 2 & 8 & 38 \\
\hline $\begin{array}{l}\text { Dendrobium } \\
\text { parciflorum }\end{array}$ & 72 & 0 & 131 & 16 & 2 & 7 & 38 \\
\hline Dendrobium henryi & 72 & 0 & 132 & 16 & 2 & 8 & 38 \\
\hline $\begin{array}{l}\text { Dendrobium } \\
\text { chrysanthum }\end{array}$ & 72 & 0 & 132 & 16 & 2 & 8 & 38 \\
\hline Dendrobium jenkinsii & 72 & 0 & 132 & 16 & 2 & 8 & 38 \\
\hline Dendrobium lohohense & 72 & 0 & 132 & 16 & 2 & 8 & 38 \\
\hline Dendrobium parishii & 72 & 0 & 132 & 16 & 2 & 8 & 38 \\
\hline $\begin{array}{l}\text { Dendrobium } \\
\text { ellipsophyllum }\end{array}$ & 72 & 0 & 132 & 16 & 2 & 8 & 38 \\
\hline Dendrobium xichouense & 72 & 0 & 132 & 16 & 2 & 8 & 38 \\
\hline
\end{tabular}




\begin{tabular}{|l|l|l|l|l|l|l|l|} 
Dendrobium fimbriatum & 72 & 0 & 132 & 16 & 2 & 8 & 38 \\
\hline Dendrobium exile & 72 & 0 & 132 & 16 & 2 & 8 & 38 \\
\hline $\begin{array}{l}\text { Dendrobium } \\
\text { fanjingshanense }\end{array}$ & 72 & 0 & 132 & 16 & 2 & 8 & 38 \\
\hline Dendrobium candidum & 75 & 0 & 128 & 0 & 0 & 8 & 38 \\
\hline Dendrobium loddigesii & 68 & 0 & 120 & 9 & 0 & 8 & 39 \\
\hline Goodyera fumata & 87 & 0 & 133 & 0 & 0 & 8 & 38 \\
\hline Goodyera procera & 80 & 0 & 127 & 0 & 0 & 8 & 39 \\
\hline $\begin{array}{l}\text { Goodyera } \\
\text { schlechtendaliana }\end{array}$ & 81 & 0 & 129 & 0 & 0 & 8 & 40 \\
\hline Goodyera velutina & 79 & 0 & 126 & 0 & 0 & 8 & 39 \\
\hline
\end{tabular}


Table 4 (on next page)

Counts of nucleotides in the chloroplast genomes 
1 Table 4. Counts of nucleotides in the chloroplast genomes.

2

\begin{tabular}{|c|c|c|c|c|c|c|}
\hline Nucleotide & $\begin{array}{l}\text { Adenine } \\
\text { (A) }\end{array}$ & $\begin{array}{l}\text { Cytosine } \\
\text { (C) }\end{array}$ & $\begin{array}{l}\text { Guanine } \\
\text { (G) }\end{array}$ & $\begin{array}{l}\text { Thymine } \\
\text { (T) }\end{array}$ & $\mathbf{C}+\mathbf{G}$ & $\mathbf{A}+\mathbf{T}$ \\
\hline Dendrobium nobile & 46576 & 28853 & 28039 & 48381 & 56892 & 94957 \\
\hline Dendrobium officinale & 46743 & 28924 & 28107 & 48447 & 57031 & 95190 \\
\hline Dendrobium strongylanthum & 46940 & 29147 & 28431 & 48541 & 57578 & 95481 \\
\hline Dendrobium huoshanense & 47032 & 29111 & 28316 & 48729 & 57427 & 95761 \\
\hline Dendrobium chrysotoxum & 47180 & 29400 & 28492 & 48881 & 57892 & 96061 \\
\hline Dendrobium nobile (China) & 47118 & 28871 & 28748 & 48923 & 57619 & 96041 \\
\hline Dendrobium pendulum & 46997 & 29122 & 28242 & 48677 & 57364 & 95674 \\
\hline Dendrobium moniliforme & 45551 & 28339 & 27520 & 47368 & 55859 & 92919 \\
\hline Dendrobium primulinum & 46191 & 28750 & 27909 & & 56659 & 94108 \\
\hline Dendrobium aphyllum & 46417 & 28917 & 28057 & 48133 & 56974 & 94550 \\
\hline Dendrobium brymerianum & 46509 & 28968 & 28123 & 48230 & 57091 & 94739 \\
\hline Dendrobium denneanum & 46440 & 28913 & 28115 & 48097 & 57028 & 94537 \\
\hline Dendrobium devonianum & 46615 & 28943 & 28108 & 48279 & 57051 & 94894 \\
\hline Dendrobium falconeri & 46591 & 28911 & 28040 & 48348 & 56951 & 94939 \\
\hline Dendrobium gratiosissimum & 46521 & 28954 & 28095 & 48259 & 57049 & 94780 \\
\hline Dendrobium hercoglossum & 46592 & 28941 & 28131 & 48275 & 57072 & 94867 \\
\hline Dendrobium wardianum & & & & & & 94715 \\
\hline Dendrobium wilsonii & 46668 & 28948 & 28101 & 48363 & 57049 & 95031 \\
\hline Dendrobium crepidatum & 46482 & 28951 & 28056 & 48228 & 57007 & 94710 \\
\hline Dendrobium salaccense & 46493 & 28635 & 27735 & 48241 & 56370 & 94734 \\
\hline Dendrobium spatella & 46524 & 28969 & 28091 & 48245 & 57060 & 94769 \\
\hline Dendrobium parciflorum & 45941 & 28699 & 829 & 47604 & & 93545 \\
\hline Dendrobium henryi & 46550 & 28936 & 28093 & 48271 & 57029 & 94821 \\
\hline Dendrobium chrysanthum & 46519 & 28939 & 28078 & 48254 & 57017 & 94773 \\
\hline Dendrobium jenkinsii & 46497 & 28942 & 28105 & 173 & 57047 & 94670 \\
\hline Dendrobium lohohense & 46558 & 28928 & 28098 & 48228 & 57026 & 94786 \\
\hline Dendrobium parishii & 46487 & 28924 & 28079 & 48199 & 57003 & 94686 \\
\hline Dendrobium ellipsophyllum & 46690 & 28922 & 28091 & 48323 & 57013 & 95013 \\
\hline Dendrobium xichouense & 46672 & 28937 & 28098 & 48345 & 57035 & 95017 \\
\hline Dendrobium fimbriatum & 46483 & 28932 & 28094 & 48164 & 57026 & 94647 \\
\hline Dendrobium exile & 46251 & 28937 & 28065 & 48041 & 57002 & 94292 \\
\hline Dendrobium fanjingshanense & 46694 & 28947 & 28115 & 48352 & 57062 & 95046 \\
\hline Dendrobium candidum & 46695 & 28914 & 28091 & 48394 & 57005 & 95089 \\
\hline Dendrobium loddigesii & 46868 & 28934 & 28064 & 48627 & 56998 & 95495 \\
\hline Goodyera fumata & 48186 & 29569 & 28447 & 49441 & 58016 & 97627 \\
\hline Goodyera procera & 47095 & 29370 & 28303 & 48472 & 57673 & 95567 \\
\hline Goodyera schlechtendaliana & 47822 & 29206 & 28146 & 49174 & 57352 & 96996 \\
\hline Goodyera velutina & 47554 & 28694 & 27658 & 48786 & 56352 & 96340 \\
\hline
\end{tabular}


Table 5 (on next page)

Counts of nucleotide frequency in codon positions across the chloroplast genomes 
1 Table 5. Counts of nucleotide frequency in codon positions across the chloroplast genomes.

\begin{tabular}{|c|c|c|c|c|c|c|c|c|c|c|c|c|}
\hline $\begin{array}{l}\text { Nucleotide per } \\
\text { position }\end{array}$ & $\mathbf{A}$ & $1 \mathrm{C}$ & $1 \mathrm{G}$ & $1 \mathrm{~T}$ & $2 \mathrm{~A}$ & $2 \mathrm{C}$ & $2 \mathrm{G}$ & $2 \mathrm{~T}$ & $3 \mathbf{A}$ & $3 \mathrm{C}$ & $3 \mathbf{G}$ & $3 \mathrm{~T}$ \\
\hline D. nobile & 0.31 & 0.19 & 0.27 & 0.23 & 0.3 & 0.2 & 0.18 & 0.32 & 0.32 & 0.14 & 0.16 & 0.38 \\
\hline D. officinale & 031 & 0.19 & 0.27 & 0.23 & 0.3 & 0.2 & 0.18 & 0.32 & 0.32 & .14 & 0.16 & 0.38 \\
\hline $\begin{array}{l}\text { D. } \\
\text { strongylanthum }\end{array}$ & 0.31 & 0.19 & 0.27 & 0.23 & 0.3 & 0.2 & 0.18 & 0.32 & 0.32 & 0.14 & 0.16 & 0.38 \\
\hline D. huoshanense & 0.31 & 0.19 & 0.27 & 0.23 & 0.3 & 0.2 & 0.18 & 0.32 & 0.32 & 0.14 & 0.16 & 0.38 \\
\hline D. chrysotoxum & 0.3 & 0.19 & 0.28 & 0.22 & 0.29 & 0.2 & 0.18 & 0.32 & 0.32 & 0.14 & 0.16 & 0.38 \\
\hline D. nobile (China) & 0.31 & 0.19 & 0.27 & 0.23 & 0.3 & 0.2 & 0.18 & 0.32 & 0.32 & 0.14 & 0.16 & 0.38 \\
\hline D. pendulum & 0.31 & 0.19 & 0.27 & 0.23 & 0.3 & 0.2 & 0.18 & 0.32 & 0.32 & 0.14 & 0.16 & 0.38 \\
\hline D. moniliforme & 0.31 & 0.19 & 0.27 & 0.23 & 0.3 & 0.2 & 0.18 & 0.32 & 0.32 & 0.14 & 0.17 & 0.38 \\
\hline D. primulinum & 0.31 & 0.19 & 0.27 & 0.2 & 0.3 & 0.2 & & & & & & \\
\hline D. aphyllum & 0.31 & 0.19 & 0.27 & 0.23 & 0.3 & 0.2 & 0.18 & 0.32 & 0.32 & 0.14 & 0.16 & 0.38 \\
\hline D. brymerianum & 0.31 & 0.19 & 0.27 & 0.23 & 0.3 & 0.2 & 0.18 & 0.32 & 0.32 & 0.14 & 0.16 & 0.38 \\
\hline D. denneanum & 0.31 & 0.19 & 0.27 & 0.23 & 0.3 & 0.2 & 0.18 & 0.32 & 0.32 & 0.14 & 0.16 & 0.38 \\
\hline D. devonianum & 0.31 & 0.19 & 0.27 & 0.23 & 0.3 & 0.2 & 0.18 & 0.32 & 0.32 & 0.14 & 0.16 & 0.38 \\
\hline D. falconeri & & & & & & & & & & & & 0.38 \\
\hline D. gratiosissimum & 0.31 & 0.19 & 0.27 & 0.23 & 0.3 & 0.2 & 0.18 & 0.32 & 0.32 & 0.14 & 0.17 & 0.38 \\
\hline D. hercoglossum & 0.31 & 0.19 & 0.27 & 0.23 & 0.3 & 0.2 & 0.18 & 0.32 & 0.32 & 0.14 & 0.16 & 0.38 \\
\hline D. wardian & & & & & & & & & & & & \\
\hline D. wilsonii & 0.31 & 0.19 & 0.27 & 0.23 & 0.3 & 0.2 & 0.18 & 0.32 & 0.32 & 0.14 & 0.16 & 0.38 \\
\hline D. crepidatum & 0.31 & 0.19 & 0.27 & 0.23 & & 0.2 & 0.18 & 0.32 & 0.32 & 0.14 & 0.16 & 0.38 \\
\hline D. salaccense & & 0.19 & 0.27 & & & & & & & & & \\
\hline D. spatella & 0.31 & 0.19 & 0.27 & 0.23 & 0.3 & 0.2 & 0.18 & 0.32 & 0.31 & 0.14 & 0.17 & 0.38 \\
\hline D. parciflorum & & & & & & 0 & & & & & 17 & 0.38 \\
\hline D. henryi & 0.31 & 0.19 & 0.27 & 0.23 & 0.3 & 0.2 & & & 0.32 & 0.14 & 0.16 & 0.38 \\
\hline D. chrysanthum & 0.31 & 0.19 & 0.27 & 0.23 & 0.3 & 0.2 & 0.18 & 0.32 & 0.32 & 0.14 & 0.16 & 0.38 \\
\hline D. jenkinsii & & & & & & & & & & & 16 & 0.38 \\
\hline D. lohohense & & 0.19 & & & & & & & & & & 0.38 \\
\hline D. parishii & 0.31 & 0.19 & 0.27 & 0.23 & 0.3 & 0.2 & 0.18 & 0.32 & 0.32 & 0.14 & 0.17 & 0.38 \\
\hline D. ellipsophyllu & 0.31 & 0.19 & 0.27 & & & 0.2 & & 0.32 & 0.32 & 0.14 & 0.16 & 0.38 \\
\hline D. xichouense & 0.31 & 0.19 & 0.27 & 0.23 & & 0.2 & 0.18 & 0.32 & & 0.14 & 0.16 & 0.38 \\
\hline D. fimbriatum & 0.31 & 0.19 & & & 0.3 & 0.2 & 0.18 & 0.32 & 0.32 & 0.14 & 0.16 & 0.38 \\
\hline D. exile & & & & & & & & & & 0.14 & 0.16 & 0.38 \\
\hline $\begin{array}{l}D . \\
\text { fanjingshanen }\end{array}$ & & 0.19 & 0.27 & 0.23 & & & 0.18 & 0.32 & 0.32 & 0.14 & 0.16 & 0.38 \\
\hline D. candidum & 0.31 & 0.19 & 0.27 & 0.23 & & 0.2 & 0.18 & 0.32 & & & 0.16 & 0.38 \\
\hline D. loddigesii & 0.31 & 0.19 & 0.27 & 0.23 & 0.3 & 0.2 & 0.18 & 0.32 & 0.32 & 0.14 & 0.16 & 0.38 \\
\hline G. fumata & 0.31 & 0.19 & 0.26 & 0.24 & 0.29 & 0.2 & 0.18 & 0.33 & 0.32 & 0.14 & 0.16 & 0.38 \\
\hline G. procera & & & & & & & & & & & & 0.38 \\
\hline $\begin{array}{l}\text { G. } \\
\text { schlechtendalia }\end{array}$ & & & & & & & & & & 0.14 & 0.16 & 0.38 \\
\hline G. velutina & 0.31 & 0.19 & 0.27 & 0.24 & 0.29 & 0.21 & 0.18 & 0.33 & 0.32 & 0.14 & 0.16 & 0.38 \\
\hline
\end{tabular}




\section{Table 6(on next page)}

Relative synonymous codon usage (in parentheses) following the codon frequency across the chloroplast genomes in the genus Dendrobium 
1 Table 6. Relative synonymous codon usage (in parentheses) following the codon frequency across the chloroplast genomes in the 2 genus Dendrobium.

3

4
5

\begin{tabular}{|l|r|r|l|r|r|l|r|r|l|r|r|}
\hline Codon & Count & RSCU & Codon & Count & RSCU & Codon & Count & RSCU & Codon & Count & RSCU \\
\hline UUU(F) & 2018.1 & 1.16 & UCU(S) & 1330 & 1.63 & UAU(Y) & 1371 & 1.38 & UGU(C) & 706.9 & 1.24 \\
\hline UUC(F) & 1459.2 & 0.84 & UCC(S) & 882.8 & 1.08 & UAC(Y) & 621.4 & 0.62 & UGC(C) & 437 & 0.76 \\
\hline UUA(L) & 918.4 & 1.14 & UCA(S) & 999.4 & 1.23 & UAA(*) & 970.5 & 1.05 & UGA(*) & 1065 & 1.15 \\
\hline UUG(L) & 970.9 & 1.21 & UCG(S) & 576.9 & 0.71 & UAG(*) & 732.2 & 0.79 & UGG(W) & 691.4 & 1 \\
\hline CUU(L) & 1068.9 & 1.33 & CCU(P) & 638 & 1.13 & CAU(H) & 919.7 & 1.43 & CGU(R) & 336.1 & 0.63 \\
\hline CUC(L) & 629.2 & 0.78 & CCC(P) & 547.8 & 0.97 & CAC(H) & 369.3 & 0.57 & CGC(R) & 220.7 & 0.41 \\
\hline CUA(L) & 762.8 & 0.95 & CCA(P) & 689.4 & 1.23 & CAA(Q) & 952.8 & 1.38 & CGA(R) & 545.2 & 1.02 \\
\hline CUG(L) & 473.7 & 0.59 & CCG(P) & 375.4 & 0.67 & CAG(Q) & 423.2 & 0.62 & CGG(R) & 343 & 0.64 \\
\hline AUU(I) & 1635.7 & 1.21 & ACU(T) & 646 & 1.21 & AAU(N) & 1580 & 1.39 & AGU(S) & 659.9 & 0.81 \\
\hline AUC(I) & 1072.9 & 0.8 & ACC(T) & 530.8 & 1 & AAC(N) & 695 & 0.61 & AGC(S) & 435.8 & 0.54 \\
\hline AUA(I) & 1337.4 & 0.99 & ACA(T) & 610.3 & 1.15 & AAA(K) & 1914 & 1.31 & AGA(R) & 1171 & 2.2 \\
\hline AUG(M) & 891.4 & 1 & ACG(T) & 343.2 & 0.64 & AAG(K) & 1009 & 0.69 & AGG(R) & 576 & 1.08 \\
\hline GUU(V) & 709.4 & 1.36 & GCU(A) & 467.5 & 1.29 & GAU(D) & 1038 & 1.43 & GGU(G) & 523.7 & 0.99 \\
\hline GUC(V) & 366.7 & 0.7 & GCC(A) & 326.4 & 0.9 & GAC(D) & 413.9 & 0.57 & GGC(G) & 314.4 & 0.59 \\
\hline GUA(V) & 647.8 & 1.24 & GCA(A) & 438.7 & 1.21 & GAA(E) & 1335 & 1.37 & GGA(G) & 754.1 & 1.43 \\
\hline GUG(V) & 366.9 & 0.7 & GCG(A) & 221.5 & 0.61 & GAG(E) & 618.3 & 0.63 & GGG(G) & 521.8 & 0.99 \\
\hline
\end{tabular}

